\title{
Innovation strategies for smart specialisation (RIS3): Past, present and future research
}

\author{
João Lopes ${ }^{1}$ (i) | João J. Ferreira ${ }^{1}$ | Luís Farinha ${ }^{2}$
}

${ }^{1}$ Department of Management and Economics \& NECE - Research Centre in Business Science, University of Beira Interior, Covilhã, Portugal

${ }^{2}$ Polytechnic Institute of Castelo CIPEC Research Center in Heritage, Education and Culture, and NECE - Research Centre in Business Sciences, Castelo Branco, Portugal

\section{Correspondence}

João Lopes, Department of Management and Economics \& NECE - Research Centre in Business Science, University of Beira Interior, Estrada do Sineiro, s/n., 6200-209 Covilhã, Portugal.

Emails: joao.lopes.1987@ hotmail.com; joao. nuno.morais.lopes@ubi.pt

\section{Abstract}

The recent change in the regional development strategy of the European Union (EU) results in an important need to study the terms of change and their respective implications. This study seeks, through a bibliometric analysis, to ascertain the developments taking place in studies on research and innovation strategies for smart specialisation (RIS3) to identify shortcomings and opportunities for future research. This bibliometric review drew upon the Scopus database with the sample selected containing all the articles containing the keywords "Research and Innovation Strategies for Smart Specialisation" or "RIS3." This correspondingly reports how some authors maintain that the path the EU should take involves imitative innovation. Meanwhile, others propose that each region should specialise in those industries that are already established there and thus avoid targeting any areas they do not already know/specialise in. Our findings detail six clusters in RIS3 research, which help in contextualising the literature review: (a) business discovery; (b) smart specialisation; (c) innovation; (d) specialisation; (e) regional policies; and (f) regional development. This study furthermore sets out perspectives for future lines of research and correspondingly seeks to convey a vast theoretical basis that may serve as the point of departure for future studies. 


\section{INTRODUCTION}

In recent years, Europe has experienced a serious financial and economic crisis even while the subsequent recession hit hardest in less competitive regions (Tiits, Kalvet, \& Mürk, 2015). Additionally, these regions also return poor rates of growth in their exports, low levels of internal consumption and still furthermore, high unemployment.

The concept of research and innovation strategies for smart specialisation (RIS3) has taken an increasingly critical role as regards European regional innovation and its development policies (Capello, 2014). Dominique Foray served as one of the founders of the European regional innovation strategy and development policy as a member of the specialist group known as "Knowledge for Growth" (Capello, 2014). This group was set up in order to advise the European Commission (Capello, 2014). Studying RIS3 inherently involves approaching the European regional policy. In this alignment, the EU deploys a national strategy for smart specialisation and that requires implementation in order to ensure the access of regions/countries to the 2014-2020 Structural Funds (Foray et al., 2012; Paliokaite, Martinaitis, \& Reimeris, 2015). Following the global financial and economic crisis that broke in 2008, Landabaso (2014b) maintains that the concept of smart specialisation has generated repercussions across various European and world economic institutions such as the Organization for Economic Cooperation and Development.

The focus on smart specialisation emerged in the EU from the year 2009. The first institutional actions of the EU consisted in the creation of a consultative body, the "Mirror Group." In 2011, the first conclusions of the "Mirror Group" gave rise to an official smart specialisation policy report in 2012 - Guide to research and innovation strategies for smart specialisation (RIS3). In academia, the first works related to the smart specialisation emerged in 2013 and have been intensifying to date. The ideas and principles underlying the creation of smart specialisation in Europe are very consistent with the work previously developed by several authors in the USA (e.g., Acs et al., 2002; Audretsch \& Feldman, 1996; Hausmann \& Rodrik, 2003; Storper \& Scott, 2009).

Originally, the smart specialisation concept emerged from discussions around the differences in trans-Atlantic productivity rates (Foray, David, \& Hall, 2009). According to Estensoro and Larrea (2016), this initially focused upon the trans-Atlantic differences observed in terms of the intensity of the ongoing research and development $(\mathrm{R} \& \mathrm{D})$ and this respectively explained differences in growth. Other authors explained this situation through recourse to the "structural effect," which highlights trans-Atlantic differences in industrial structures. The EU industrial structure is disproportionately characterised by traditional sectors, with average or low technology levels that result in lower levels of ability to transform R\&D developments into productivity gains. These authors subsequently explain this as due to the "intrinsic effect," which conveys how even within the same sectors, European companies demonstrate lesser abilities in converting R\&D progress into productivity or other types of gains (McCann \& Ortega-Argilés, 2014a). McCann and Ortega-Argilés (2014a) argue that there are limitations to the knowledge transfer mechanisms between sectors and companies and also between different regions. They refer to how these stem from the heterogeneity in the EU integration process, which serves to complicate the capacity to spread the various benefits of new but already generated R\&D to all sectors and industries.

Academic studies applying bibliometric reviews of the literature enable the understanding of patterns in the themes and writing as well as in the articles deploying statistical analysis (Lancaster, 1991; Souza, 1988). The bibliometric approach involves a research technique that analyses the size, growth and distribution of the bibliography on a particular field of knowledge. According to Freire (2013), bibliometrics is a technique for evaluating and measuring the results of bibliographic research into a specific research question or about a specific variable. 
The articles published about RIS3 tend to be very centred on either the process of designing RIS3 or on its implementation (Camagni \& Capello, 2013; McCann, Landabaso, \& Ortega-Argilés, 2014; Morgan, 2016). Hence, this led to the identification of a shortcoming in the literature with the lack of any bibliometric studies on the theme here under analysis. These studies hold great relevance both to grasping the concept and its development and progress over time.

The RIS3 theme remains relatively recent having first emerged in 2013. As stated above, the existing studies tend to approach the design and implementation of RIS3 and we are therefore not yet able to clearly understand this concept and its implications for regional development. The contribution of the article is to undertake a bibliometric analysis to demonstrate how conceptual and policy ideas develop and spread and are interpreted or emphasised in different ways by different scholars. In order to carry out this bibliometric review, we made recourse to the Scopus database and applied certain filters in order to exclude those publications not of relevance to our study. The selection filter applied considered both the articles and the scientific fields of greatest relevance to this theme.

Thus, the objectives include verifying changes and trends in this field as well as identifying the most prominent subthemes. This correspondingly seeks to open up new horizons for future publications as well as also revealing the most relevant authors and journals on this theme. Identifying the authors that have produced the most studies and articles clearly answers the important need to grasp just how, when and where interest in this theme emerged. This approach additionally pinpoints those studies that served as the foundations for building research on this theme. Following this study, future researchers in this field may access details about just which journals have published what articles as well as visualising the quality of those articles.

This also extends to a literature review to ensure a better understanding of this theme. This review approaches the subthemes such as "regional development," "smart specialisation" and "entrepreneurial discovery" in addition to any others encountered within the framework of undertaking this review.

The structure of this article is as follows: following this introduction, we move onto setting out the literature review. Thirdly, we detail the methodology applied before analysing and discussing the results returned. Finally, we provide our conclusions while identifying limitations to this study alongside future lines of research.

\section{I LITERATURE REVIEW}

\section{1 | The smart specialisation concept and RIS3}

Economic growth represents the final goal of specialisation and development, which in turn requires the generation and development of knowledge. Tiits et al. (2015) detail how the objective of this development encapsulates the establishing of unique advantages that competitors find difficult to copy. The concepts of knowledge, technology, innovation and specialisation interconnect with the core concepts for the growth and development of any economy (Fagerberg, 2005; Schumpeter, 1950). Hence, we may state that smart specialisation includes a process of developing a vision, identifying the strengths and weaknesses of the surrounding territory, defining the strategic priorities and making use of intelligent policies to maximise the scope for the progress and advancement of knowledge in regions (Iacobucci, 2014).

The Strategy for Europe 2020 defines and measures intelligent growth according to the conceptual frameworks in effect, thus, according to the role of technological evolution in human capital and of knowledge to economic growth and regional convergence (Jaffe, 1989; Rauch, 1993). This growth strategy, in turn, inherently casts its focus upon innovation, knowledge and technology (Naldi, 
Nilsson, Westlund, \& Wixe, 2015). It might be said that the idea of specialisation has existed for as long as economic theory, with its foundational works featuring lengthy discussion of the specialisation and learning ongoing in the pin factory (Smith, 1991). However, the first recorded reference to the term smart specialisation took place in 2008 (Foray, David, \& Hall 2011). According to Foray et al. (2011), this also extends to the needs for political decision makers to make choices, through public policies, as regards the technologies and the sectors that should be supported. McCann and Ortega-Argilés (2014a), in turn, refer to how when the concept first emerged, it was independent of any regional dimension or explicit geographic reference.

Both the European Union and the United States of America work to develop specific smart specialisation policies and strategies to improve existing opportunities, change economic institutions and improve the competitiveness of countries and regions (Falcomatà, Nucera, \& Tripodi, 2014). In the alignment of the smart specialisation strategy policy, the formation of industrial clusters makes an important contribution to the development of the regions (Titze, Brachert, \& Kubis, 2014; Yu \& Jackson, 2011). According the Barroeta, Gómez Prieto, Paton, Palazuelos Martinez, and Cabrera Giraldez (2017), policy makers of Latin America are considering the Smart Specialisation concept as an inspirational driver of RIS. In addition, smart expertise at the regional level serves to strengthen innovation processes with local stakeholders.

Regions or countries with small economies are encountering ever more difficulties in competing with the large economies deploying state-of-the-art technology (Tiits et al., 2015). Some authors also maintain that small economies attain only more limited levels of diversification, innovative capacity and production (Tiits, Kattel, Kalvet, \& Tamm, 2008; Walsh, 1988).

RIS3 took over from the learning built up on regional innovation systems, which constituted the basis for the development of regional economic policies over recent years (Asheim \& Gertler, 2005; Cooke, 2001). Indeed, RIS3 effectively represents an evolution of regional innovation systems. Some authors consider this change in paradigm in Europe to have been rather abrupt (Foray, 2014b; Kroll, 2015b).

RIS3 effectively complements everything set out above for the smart specialisation concept. RIS3 seeks to identify knowledge in selective "domains," alongside the priorities, in areas in which the regions (or a member state) hold a relative advantage (Foray, 2014a; Foray et al., 2012), which may turn into a competitive advantage. Camagni and Capello (2013) indicate how RIS3 consists of investing in knowledge and human capital, industrial capital and technology as well as in the competences of territories. Hence, RIS3 highlights the role played by knowledge, technology and innovation in economic development and social well-being (Tiits et al., 2015). Tiits et al. (2015) portray RIS3 as designed as a means to transform R\&D into the creation of new policies, thus, the concept fundamentally focuses on the economic returns generated by R\&D.

The implementation of RIS3 in economies with better developed R\&D systems may thus result in the production of new and intensive activities containing a strong science component (Foray et al., 2009; Foray et al., 2012). On the other hand, the lesser developed economies should focus their R\&D strategies on areas where they already have industries in operation (Foray et al., 2009; Foray et al., 2012). According to Healy (2016), one of the main characteristics of the RIS3 approach stems from its territorial focus, whether at the national or regional level. Healy (2016) correspondingly maintains that this led to a multifaceted approach with some member states putting forward national strategies, others proposing regional strategies and still others combining a mixture of the two.

According to Foray et al. (2011), political policies and theories have experienced a growing distancing. The concept has furthermore come in for criticism due to its approaching all regions as equal (Torre \& Wallet, 2013). For example, Cooke (2012) criticises both the theoretical and the implementation of RIS3, pointing to an exaggerated emphasis on science and technology resulting in innovation 
overly focused on high technology sectors. Other authors opt in favour of imitation based innovation as the most appropriate approach (Capello \& Lenzi, 2013), thus, through benchmarking. Despite these two divergent opinions, there is also a set of authors that deem taking a strong orientation towards the definition of the traditional priorities represents the best path forward rather than returning to priority objectives selected in accordance with more general categorisations (Iacobucci, 2014).

\section{2 | Entrepreneurial discovery}

Inherent to any approach to RIS3 is understanding and encapsulating the concept underlying the process of entrepreneurial discovery. Thus, we may correspondingly state that the concept of entrepreneurial discovery lies at the core of RIS3 (Santini, Marinelli, Boden, Cavicchi, \& Haegeman, 2016). Santini et al. (2016) maintain that this concept also spans the need to ensure both private and public R\&D in any particular territory. Mutual collaboration also emerges as an objective within the framework of identifying the key sectors for sustainable development (Santini et al., 2016). Furthermore, according to Hausmann and Rodrik (2003), the process of entrepreneurial discovery constitutes a business process of trial and error, success and, most relevantly, failure.

Tiits et al. (2015) structure RIS3 in accordance with the priorities prevailing and with its key decisive characteristics emerging from this process of entrepreneurial discovery. Entrepreneurial discovery differentiates smart specialisation in the traditional industries from innovation policies (Landabaso, 2014a). Foray (2013) describes this process as depending on the capacities for observation, detection and filtering on behalf of political decision makers. Foray (2014a) then details entrepreneurial discovery as a dynamic and decentralised process that should certify the transformation in productive structure through continuously drawing upon the ongoing research and innovation. Santini et al. (2016) refer to how entrepreneurial discovery requires the interaction between thinkers and doers, thus, this interaction has to arise out of the shared identification by the respective stakeholders of the core priorities for regional development. This expects the regions or countries undertaking entrepreneurial discovery processes to focus upon the already existing national/regional strengths (Asheim et al., 2011). Asheim et al. (2011) affirm how these need to nurture a variety of relations and, based upon the competences, means and capacities existing, to develop new paths for growth, sectors and alongside the modernisation of "traditional" industries.

The entrepreneurial discovery process requires governments and authorities play a distinct role in the performance of their industrial policies and in traditional innovation (Coffano \& Foray, 2014; Foray et al., 2009). Thus, according to Coffano and Foray (2014), a large proportion of regions are already engaged in change through moving on from structural analysis of the "easy to do" to that of entrepreneurial discovery ("difficult to do"). Various authors have also approached this challenge (Kroll, 2015a; Ortega-Argiles, 2012).

Ahlqvist et al. (2012) affirm that what differentiates between smart specialisation or RIS3 based industrial policies and traditional innovation arises out of this focus on entrepreneurial discovery. They convey how this represents a process of collective bottom-up reflection that attributes a key role to market forces and private actors, thus, those providing information on new activities and strategies for specialisation are able to return social and economic impacts on regions.

\subsection{Difficulties in implementing RIS3}

Smart specialisation did not get originally designed as a strategy but was rather planned on a top-down basis, from the government to the companies (Estensoro \& Larrea, 2016; McCann \& Ortega-Argilés, 2014a). 
According to Estensoro and Larrea (2016), there are inherent difficulties to developing these processes.

One difficulty emerging out of the implementation of RIS3 relates to learning as there have been inconsistencies in academic outputs (Capello, 2014; Kroll, 2015a). Thus, this may well reflect how the regional authorities experienced confusion when actually attempting to put the concept into practice (Capello, 2014; Kroll, 2015a).

Foray et al. (2011), based on the work produced by Hausmann and Rodrik (2003), conclude that smart specialisation has to derive from a process of entrepreneurial discovery undertaken by companies and the other organisations acting upon the economy. The process of discovery necessarily has to involve the companies as they constitute the only entities able to effectively identify just what may or may not be competitively produced in a particular time and place (Healy, 2016). However, as regards the discovery process, the bulk of the literature emphasises the importance of the regions or member states identifying in economic terms just what and where are the potentials for obtaining this soughtafter competitive advantage (Boden, Marinelli, Haegman, \& Dos Santos, 2015). Some authors affirm that any strategic process planned on a bottom-up basis incurs the risk of poorly investing public resources (Camagni, Capello, \& Lenzi, 2014; Capello, 2014). Iacobucci (2014), however, maintains the contrary, thus, concluding that the companies and firms better know the realities of the market than government members of staff are able to spot opportunities. Therefore, even when the stakeholders are invited to participate in the process, a top-down approach is always effectively present in the choices over the "domains" for the specialisations selected, thus, correspondingly always dependent on whoever is leading the strategy—-the regional government (Estensoro \& Larrea, 2016).

McCann and Ortega-Argilés (2015) affirm the need for smart specialisation strategies to incorporate the local elites as a means to obtain local knowledge and thereby tailor the policies implemented.

Some authors propose that the reason for which RIS3 encounters these implementation difficulties stems from the role of the government and, in particular, from the lack of a public business sector (Landabaso, 2014a).

McCann and Ortega-Argilés (2014a) approach the institutional challenges resulting from implementing more flexible governance in conjunction with how the promotion, enhanced awareness and the diffusion of knowledge serves to improve technology and adaptation. This implementation problem in conjunction with the lack of capacities of regional actors and administrators to plan the strategic processes inherent to RIS3 also raises concerns (Estensoro \& Larrea, 2016).

Iacobucci (2014) highlights how R\&D and innovation are subject to the innovation performance prevailing in the region and the general lack of core factors for smart specialisation may indeed condition the capacity for implementation (Capello, 2014).

\section{3 | RESEARCH OBJECTIVES AND METHODOLOGY}

Being that RIS3 a recent concept and still little explored by researchers, it is important to understand how, when and where the interest in this topic arose. The articles published on RIS3, as a rule, focus on the RIS3 design process or its implementation (Camagni \& Capello, 2013; McCann et al., 2014; Morgan, 2016).

RIS3 is still little explored by researchers and is important to understand when and where the interest in this subject arose. The articles published on RIS3, as a rule, focus on the design process of RIS3 or its implementation (Camagni \& Capello, 2013; McCann et al., 2014; Morgan, 2016).

Table 1 shows the analyses that will be carried out to reach the proposed objectives. 


\section{1 $\mid$ Method}

In order to be able to study this theme, we carried out an extensive search of the Scopus database applying the keywords of Research and Innovation Strategies for Smart Specialisation and its abbreviation RIS3 (Figure 1). This search took place on 10 October 2016 and correspondingly returning a compilation of all the bibliography of all the articles published on this research theme, in this database. We then classified the 51 publications in accordance with their respective thematic fields: social sciences, business, management and accountancy, economics, econometrics and finance, engineering, decision making sciences, agriculture and biology, computer sciences, environmental sciences, medicine, physics and astronomy, biochemistry, genetics and molecular biology, chemical engineering, energy, pharmacology, toxicology and pharmaceutics, psychology and veterinary science.

In order to analyse all of the information gathered, the data were exported into Microsoft Excel 2016 in conjunction with all of their respective recorded details (authors, title, journal, country, keywords, summary and citations) (Zhi et al., 2015). To define and exclude publication without any interest to analysis of this theme, we then applied some filters.

From the selected keywords (RIS3 and Research and Innovation Strategies for Smart Specialisation), 51 publications were extracted from the Scopus database. From this universe of publications (which includes articles, chapters of books, books, lecture presentations, etc.), we methodologically have obtained a total of 42 articles (Pelletier, Gill, Shi, Birch, \& Karmali, 2013). Of the total of 42 articles, 7 articles were excluded after the second filter, which includes the scientific fields related to the central scope of this study: "Social Sciences," "Business, Management and Accounting," "Economics, Econometrics and Finance," "Decision Sciences" and "Environmental Science" (Maziak, Meade, \& Todd, 1998). Thus, a total of 35 articles were selected for the review. (Figure 1 and Annex 1).

We applied the VosViewer and Nvivo11 software programs for undertaking the bibliometric analysis. VosViewer served both for establishing the "Network of Co-Authors" and for verifying which were the most relevant subthemes to the study of this field. In turn, Nvivo11 provided the means to verify just which words were most frequently repeated across these 35 articles.

\section{ANALYSIS AND DISCUSSION OF THE RESULTS}

\section{1 $\quad$ Trends in publications}

With a total of 35 articles resulting from the selection criteria applied to the Scopus database, we may report the following trend in publications. Figure 2 thus displays the growth in publications on the theme under study over recent years.

TAB LE 1 Objectives and applied analyses

$\begin{array}{lc}\text { Objectives } & \begin{array}{c}\text { Applied analyses } \\ \text { Uunderstand when and where the interest in RIS3 }\end{array} \\ \begin{array}{ll}\text { Graphic with the } \\ \text { evolution of publications }\end{array} \\ \text { Check the authors and magazines that publish more in the subject } & \begin{array}{c}\text { Tables with number of } \\ \text { published articles and } \\ \text { citations }\end{array} \\ \text { Verify "Co-Author Network" } & \text { VosViewer analysis } \\ \text { Verify changes and trends in RIS3 } & \text { VosViewer analysis }\end{array}$




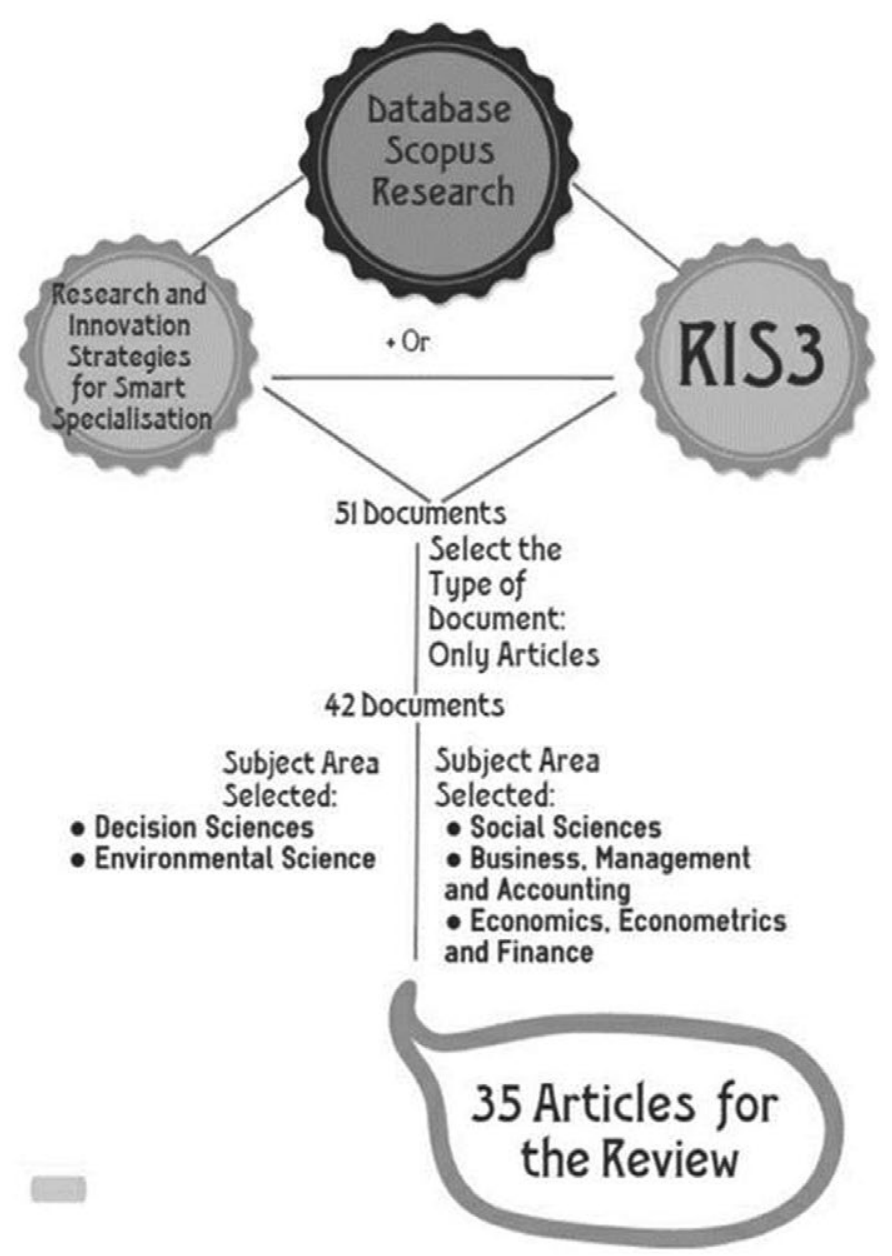

F IGURE 1 Summary of methodology

Through Figure 2, we are able to clearly understand how the first study on this theme entered the public domain in 2013. We may furthermore assert that 2013 was the year when the authors Camagni and Capello (2013), with their article "Regional innovation patterns and the EU regional policy reform: Toward smart innovation policies," began triggering interest in this theme. In 2014, the number of publications rose exponentially up to 10 before finishing 2015 with 12 articles. We would highlight how 2016, despite not then having come to a close, already accounted for 12 articles.

The interest in this theme boomed following the unveiling of a new European strategy for the 2014-2020 period. Correspondingly, the European Regional Development Fund and the European Commission set as a pre-requirement that all EU member states and regions draft an RIS3 plan prior to the approval of their operational programmes (EC, 2014). The formal responsibility for complying with this condition was set at the member state level (Valdaliso et al., 2014). According to Valdaliso et al. (2014), there has also been diversity in the level of regional involvement depending on the level of political autonomy experienced by regions across different countries. These represent the main motives that led researchers to begin studying this theme. 


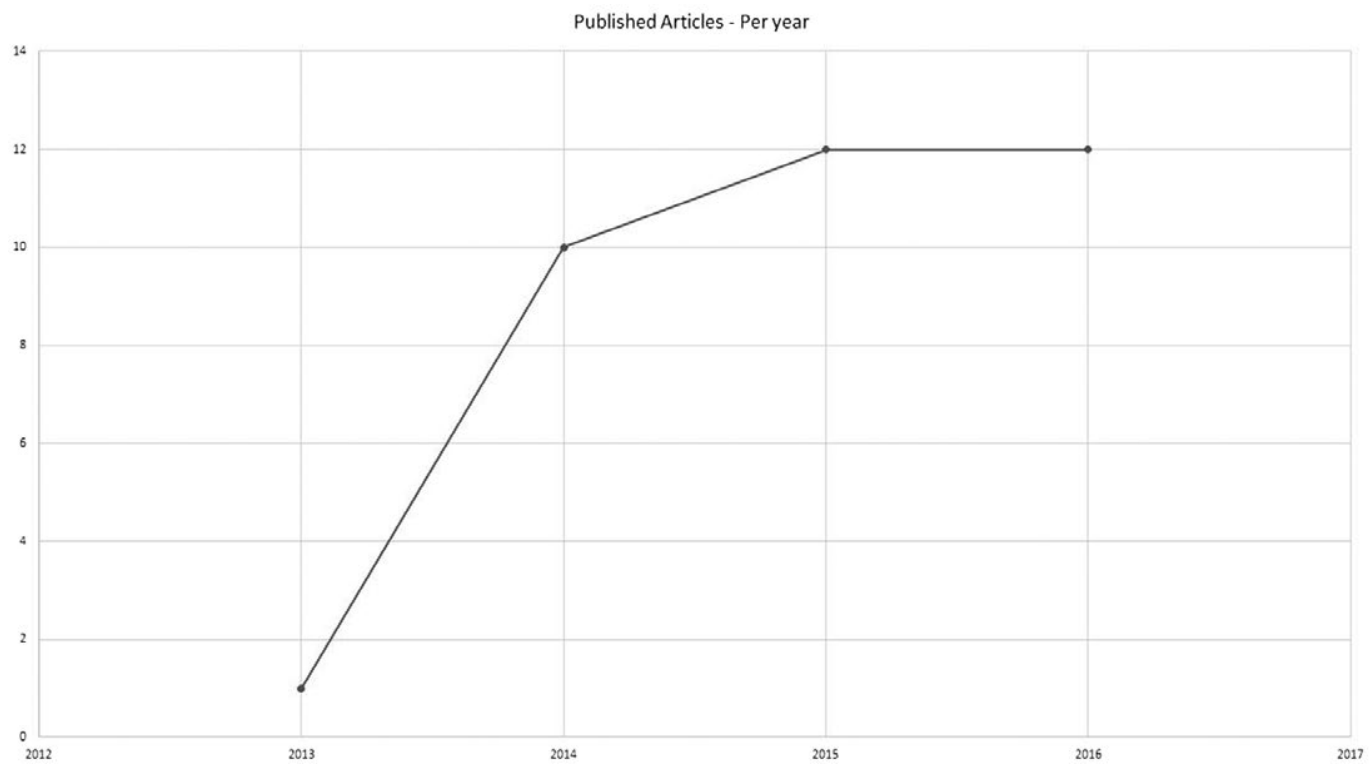

F IG URE 2 Evolution of publications per year

\section{2 | Contributions by country}

To grasp just which countries have most contributed with publications on this theme, we verified the nationalities of the authors and co-authors of the 35 selected articles (Figure 3). Thus, we here seek to evaluate the contribution made by the respective countries to deepening the literature on this area.

As set out in Figure 3, the country that most contributes to advancing the literature on this theme is Spain with a total of eight articles. This stems from three different reasons (McCann et al., 2014):

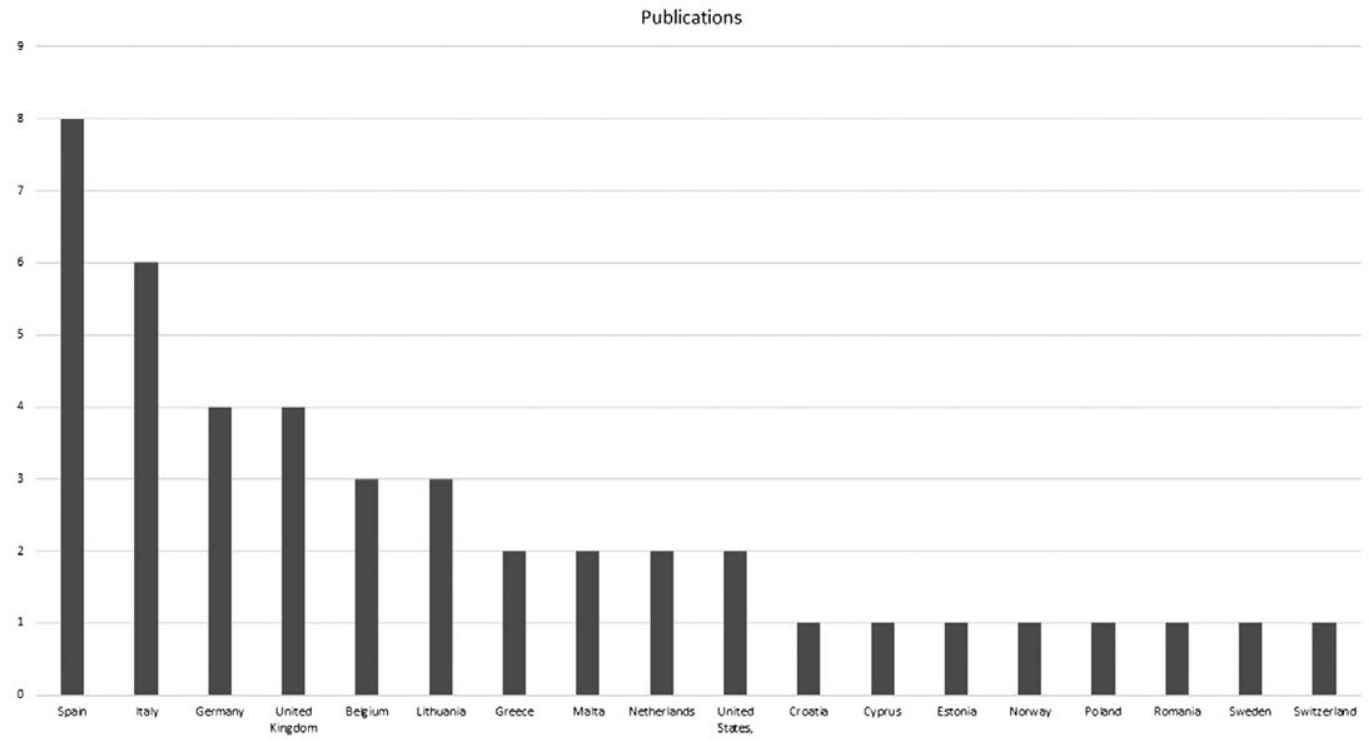

F I G U RE 3 Contributions by country 
(a) following the global financial crisis of 2008, Spain faced the problem of sheer disparities existing in its labour market; (b) there is ongoing criticism of the modernisation of many of the employment market profiles in Spain. To this end, technological training and the information and communication technologies, both in the private and the public sectors, require profound improvement; and (c) many Spanish regions need to foster a stronger sense of business culture as well as deeper connections between entrepreneurship and the regional innovation systems.

In second place came Italy with a total of six publications followed by Germany and the United Kingdom with four articles apiece. Standing on three publications apiece were Belgium and Lithuania, followed by Greece, Malta, the Netherlands and the United States with two articles. Finally, there were a number of countries with but one publication (Croatia, Cyprus, Estonia, Norway, Poland, Romania, Sweden and Switzerland).

\section{3 | Performance of authors}

This analytical procedure seeks to identify the patterns and trends through studying the citations (Ferreira, 2011; White \& Griffith, 1981; White \& McCain, 1998). In order to ascertain just which authors and co-authors published these 35 articles, we drafted the following table displaying both the number of articles published and their respective citations (Table 2).

As shown by Table 2, there are 80 authors/co-authors for these 35 articles that generate a total of 112 citations. We would highlight how Camagni and Capello (2013) each account for 51 citations apiece as they were the first to study this theme as stated above. The majority of the studies by Capello R. approach issues surrounding economic and regional development, for example Camagni, Capello, and Nijkamp (1998), Capello (2009) and Capello (2007). In the case of Camagni R., the research focus also primarily falls upon the area of economic and regional development, for example Camagni (2002), Camagni (1998) and Camagni (2009).

We may also observe that there are a group of authors standing out with two published articles: Camagni R., Kroll H., and Reimeris R. with all other authors or co-authors having published but a single article. We may also state here that those articles receiving the most citations also constitute those holding the greatest influence over the theme here under study (Tahai \& Meyer, 1999).

In order to verify the networks that the authors form, as well as if they prefer to work in groups or individually, to better study RIS3, the "Co-Author Network" will be elaborated. In order to grasp the interconnections among the authors and co-authors, we set out the "Co-Author Network" through recourse to VosViewer software (Figure 4).

As displayed in Figure 4, the VosViewer software program returned 32 clusters. There are three clusters containing five authors with this representing the maximum number of authors present in any article from among the 35 selected (Aranguen M.J.; Castillo N.; Georghiou L.; Harper J.C.; Kleibrink A.; Magro E.; Navarro M.; Niehaves B.; Palop P.; Scerri R.S.; Sörvik J.; Thapa B.E. P.; Valdaliso J.M.; Wilson J.R.). In turn, there are four authors gathered into three clusters (Böke I.; Kroll H.; Schiller D.; Stahlecker T.; Gianelle C.; Goenaga X.; Thissen M.; Vázquez I.G.; Naldi L.; Nilsson P.; Westlund H.; Wixe S.). In turn, there are a total of nine clusters with either three authors or two authors. Finally, single authors constitute another eight clusters, thus, authors preferring to work on an individual basis (Cooke P.; Fabbri E.; Foray D.; Healy A.; Iacobucci D.; Landabaso M.; Mestanza G.C.; Morgan K.). Therefore, we may hereby state that these authors most commonly approached their studies in groups of two or three.

Of the authors who have two published articles (Reimeris R and Kroll H.) among the 35 selected, we may not conclude that they preferred to work either individually or in group. The author Capello 
节

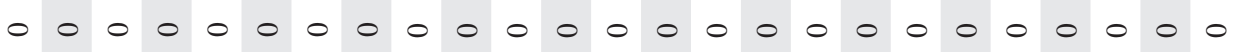

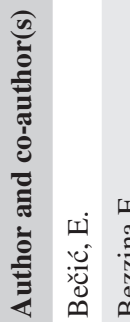<smiles>C1=CC=CC=CC=CC=CC=C1</smiles>

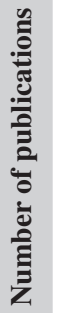

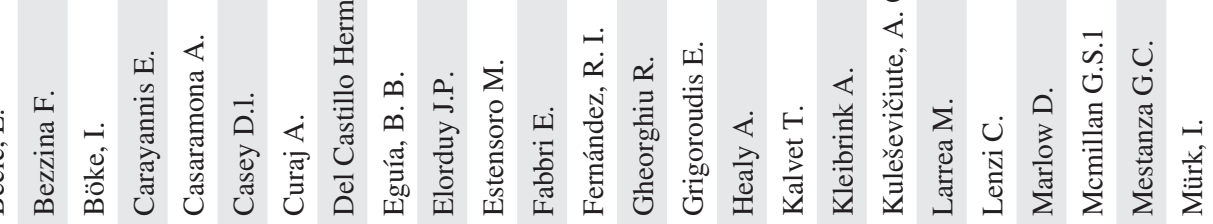

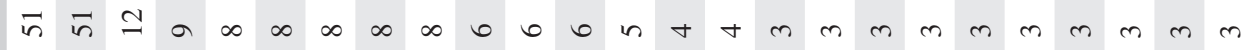

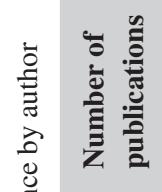

:

म

हี

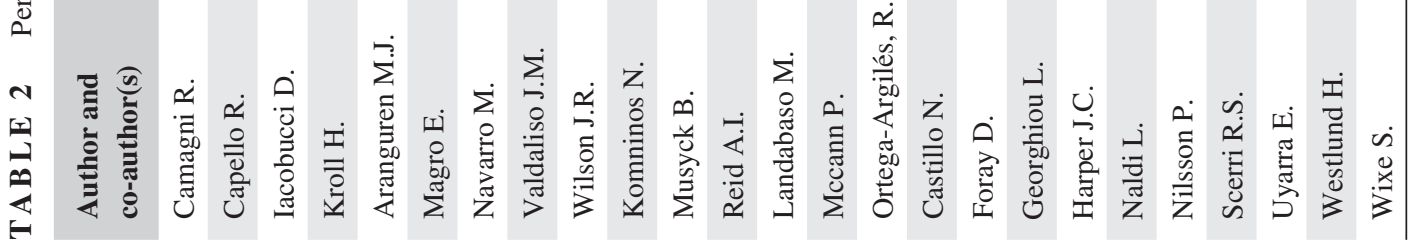


000000000000000

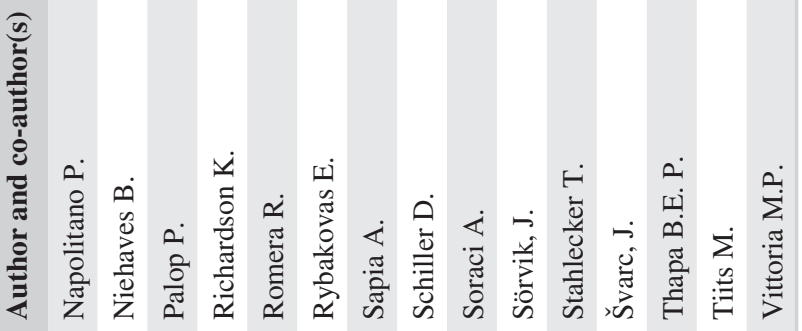



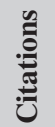

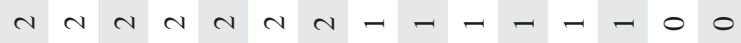

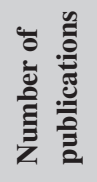

MInIm) 


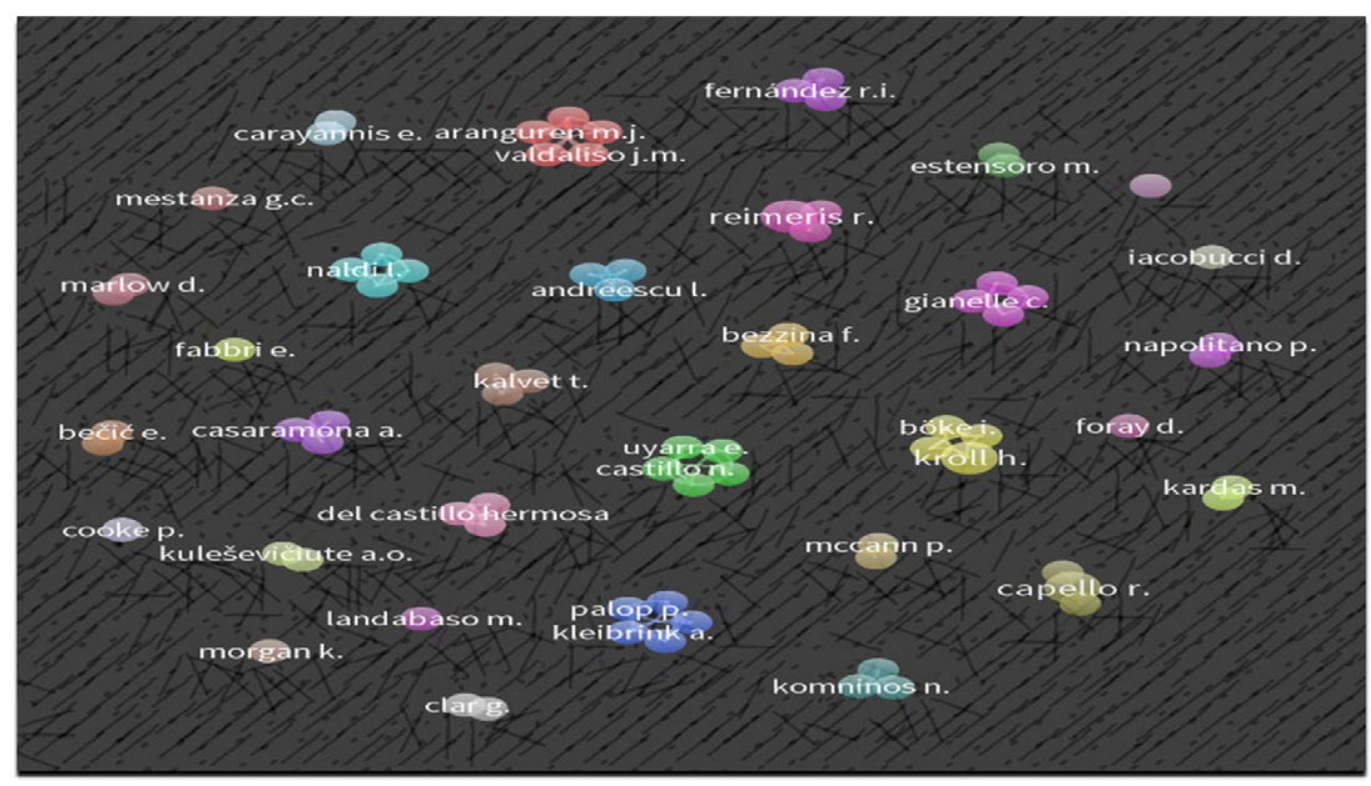

F I G U RE 4 Co-Author Network

R. has two published articles with one as an author and the other as a co-author. This author worked in group for the two respective articles.

\section{4 | Performance by journal}

In this section, we approach the performance of the journals turning their attentions to this theme. We started out by verifying the number of articles published in each journal and then followed by the respective citations (Table 3). This seeks to reflect the quality of the journals and their respective countries of origin.

As Table 3 duly details, 17 journals account for the 35 articles analysed. The European Planning Studies journal is the single most relevant source for the theme. This journal published 8 of the articles with a total of 11 citations. Secondly, there comes the European Journal of Innovation Management with 7 articles published and 31 citations with the Journal of the Knowledge Economy also playing a prominent role with 6 articles published with 2 citations.

In terms of citations, there is also the Growth and Change journal with its 51 citations for but one single article. This situation stems from its publication of the first study on the theme "Regional innovation patterns and the EU regional policy reform: Toward smart innovation policies" by Camagni and Capello (2013). Furthermore, another journal, Scienze Regionali, also stands out for the 14 citations achieved by "Designing and implementing a smart specialisation strategy at the regional level: Some open questions" by Iacobucci (2014).

As regards journal quality, they rank from Q1 to Q4. However, Q3 attains the highest level of incidence in accounting for five of the journals.

In terms of the host countries of each journal, the United Kingdom stands to the fore and accounting for 8 of the 17 journals identified. The journals do contain a Portuguese publication, the Revista Portuguesa de Estudos Regionais that has but a single article, without any citations entitled "Smart specialization and entrepreneurial discovery: Theory and reality" by the authors Del Castillo Hermosa, Elorduy, and Eguía (2015). 
TA B LE 3 Performance by journal

\begin{tabular}{|c|c|c|c|c|}
\hline Journal & Articles & Citations & Quartile (2016) & Country \\
\hline Growth and Change & 1 & 51 & Q3 & United Kingdom \\
\hline $\begin{array}{l}\text { European Journal of } \\
\text { Innovation } \\
\text { Management }\end{array}$ & 7 & 31 & Q2 & United Kingdom \\
\hline $\begin{array}{l}\text { European Planning } \\
\text { Studies }\end{array}$ & 8 & 11 & Q1 & United Kingdom \\
\hline Scienze Regionali & 1 & 11 & Q2 & Italy \\
\hline $\begin{array}{l}\text { Journal Of Rural } \\
\text { Studies }\end{array}$ & 1 & 3 & Q1 & United Kingdom \\
\hline $\begin{array}{l}\text { Technological } \\
\text { Forecasting and } \\
\text { Social Change }\end{array}$ & 1 & 2 & Q1 & United States \\
\hline $\begin{array}{l}\text { Journal of the } \\
\text { Knowledge Economy }\end{array}$ & 6 & 2 & Q2 & Germany \\
\hline $\begin{array}{l}\text { Environment and } \\
\text { Planning C: } \\
\text { Government and } \\
\text { Policy }\end{array}$ & 1 & 0 & Q1 & United Kingdom \\
\hline Foresight & 1 & 0 & Q3 & United Kingdom \\
\hline Futures & 1 & 0 & Q2 & United Kingdom \\
\hline $\begin{array}{l}\text { International Journal } \\
\text { of Technology } \\
\text { Intelligence and } \\
\text { Planning }\end{array}$ & 1 & 0 & Q4 & United Kingdom \\
\hline $\begin{array}{l}\text { Investigaciones } \\
\text { Regionales }\end{array}$ & 1 & 0 & Q3 & Spain \\
\hline $\begin{array}{l}\text { Public Policy and } \\
\text { Administration }\end{array}$ & 1 & 0 & Q3 & United States \\
\hline $\begin{array}{l}\text { Revista De Estudios } \\
\text { Regionales }\end{array}$ & 1 & 0 & Q4 & Spain \\
\hline $\begin{array}{l}\text { Revista Portuguesa de } \\
\text { Estudos Regionais }\end{array}$ & 1 & 0 & Q3 & Portugal \\
\hline $\begin{array}{l}\text { Social Network } \\
\text { Analysis and Mining }\end{array}$ & 1 & 0 & - & Switzerland \\
\hline $\begin{array}{l}\text { Foresight and STI } \\
\text { Governance }\end{array}$ & 1 & 0 & - & Russia \\
\hline
\end{tabular}

\section{5 | Subthemes and keywords}

This research technique, through the analysis of densities, allows the researcher to focus the object of study of his research on the most used keywords. We verified the words most frequently repeated over the course of these 35 articles via the Nvivo11 software program (Figure 5). 


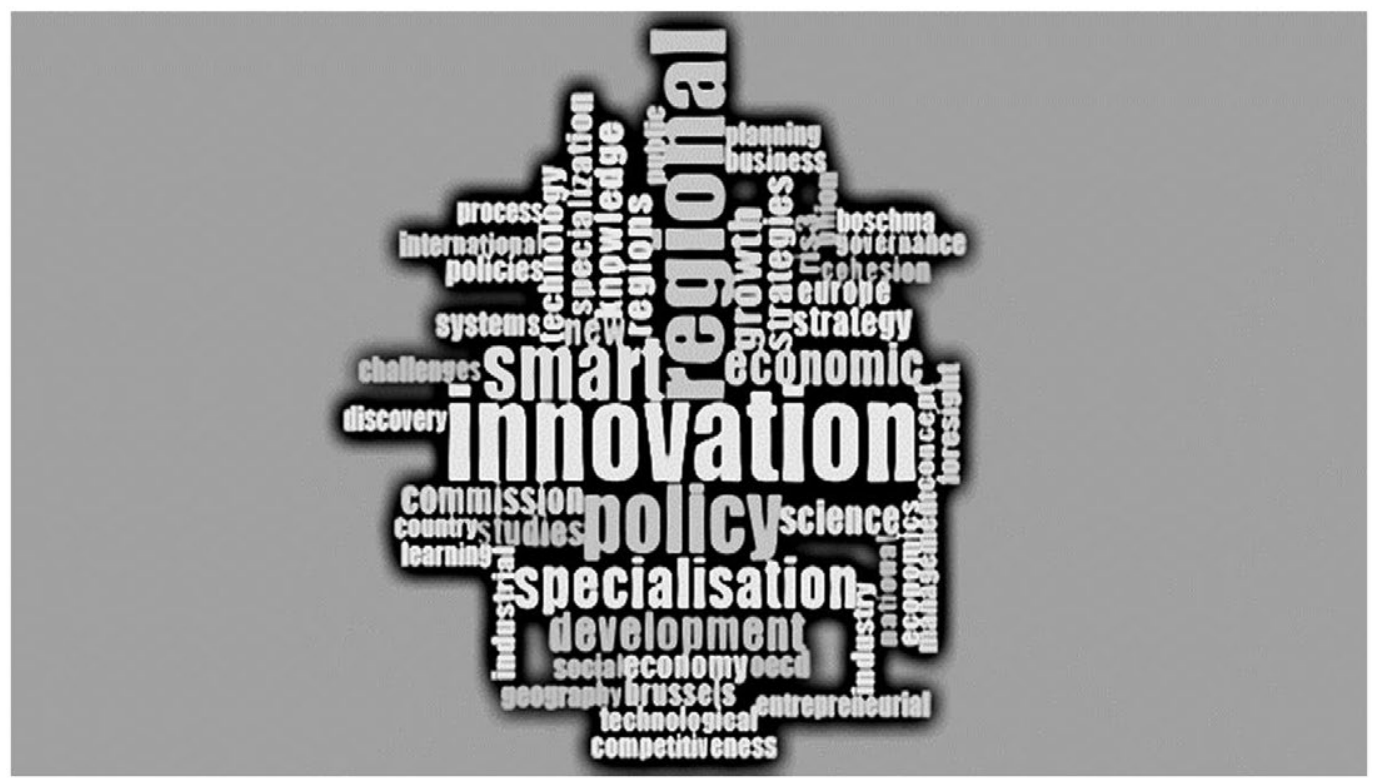

F IG URE 5 Keywords

Figure 5 displays the 50 most used words in the 35 articles. There follows below a description of the five words that returned the highest level of frequency. Derivative words were considered as holding an equivalent value.

Firstly, the word "Innovation" got repeated a total of 617 times. Secondly came the word "Regional" with 518 different repetitions and trailed by the word "policy" used on 419 occasions. Fourthly, with 389 repetitions, comes the word "Smart" before the word "Specialisation," repeated 269 times, which closes the list of the most common five words. We would emphasise that "RIS3" also makes it into the top 50 most utilised words with a total of 92 usages.

In order to grasp the most relevant subthemes to this theme, we again turned to VosViewer software to analyse the most outstanding themes from the analysis of densities.

To understand the results of the VosViewer analysis, we need to understand the meaning of the colours. As Figure 6 features, there are three colours displaying different levels of density. The green colour indicates that the subtheme has broadly been overlooked by RIS3 studies and hence displays a minimum density level. The colour yellow identifies an intermediate level for the subtheme identified and therefore average density. Finally, the colour red highlights how this is a subtheme on which researchers have most closely focused and therefore attaining the highest level of density.

As seen in Figure 6, the VosViewer results portray six clusters of subthemes that are relevant to the theme of study (smart specialisation; innovation; business discovery; specialisation; regional policies; regional development). This thus clearly displays how smart specialisation and innovation, coloured red, attain the highest levels of density followed by the entrepreneurial discovery cluster with an average density. These three clusters take on great importance to the theme under analysis and should receive still greater focus. Green is the colour characterising the remainder of the clusters that, despite only attaining a low level of density, also require consideration by studies on this theme. The clusters with weak density levels (coloured green) may also pinpoint new trends that are emerging in the literature.

In order to identify the ways in which these clusters fall into the framework made up of the 35 articles, we then analysed all the titles and summaries. We would reference that the majority of the articles 


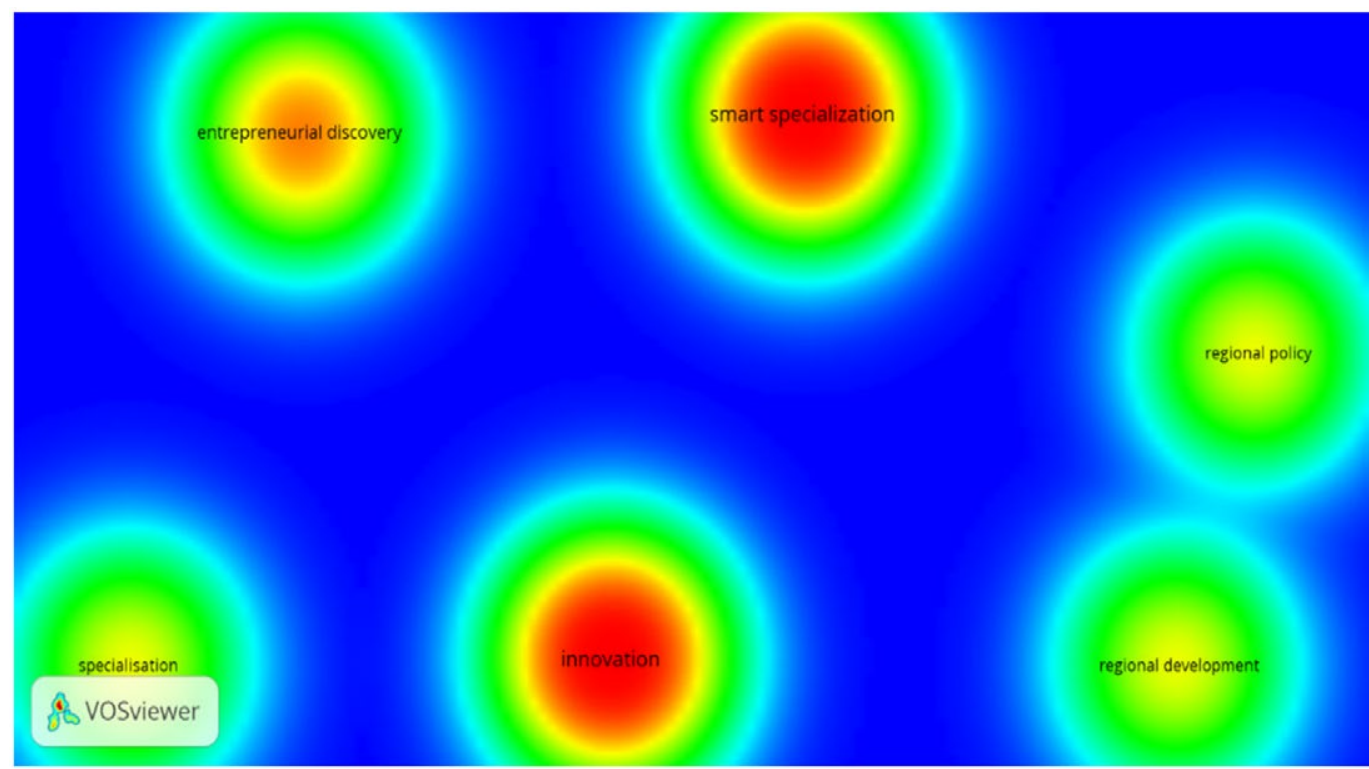

F I G URE 6 Clusters-density

fall within the scope of more than one subtheme (Table 4). The cluster numbers are the following: cluster 1-business discovery; cluster 2-smart specialisation; cluster 3-innovation; cluster 4-specialisation; cluster 5-regional policy and cluster 6-regional development.

As shown, the 35 articles all form into a total of 6 clusters as displayed in Figure 6. Cluster 1 incorporates 14 articles with clusters 2, 3 and 4 each including all 35 articles while cluster 5 spans 22 articles and with cluster 6 including 20 articles.

Cluster 4, although it appears in Figure 6 with the color green, can be considered to be part of cluster 2. In this specific topic, specialisation is usually associated with smart specialisation. Thus, it can be affirmed that clusters 1, 5 and 6 are less studied than the others. In this sense, it becomes pertinent that future investigations be developed in these subthemes.

The sub-points below select and describe some of the articles that attain the greatest relevance to the theme under analysis and that effectively summarise it. Thus, the articles selected are those that most clearly and explicitly focus on the six subthemes/clusters identified above whilst also taking into consideration the non-repetition of the articles in the different sub-points. As clusters 2, 3 and 4 encapsulate all of the articles, there is only one sub-point for these three clusters.

\subsection{1 | Business discovery (cluster 1)}

The "Smart specialisation strategies in south Europe during crisis" article by Komninos, Landabaso, Musyck, and Iain Reid (2014) identifies three paths to a more intelligent productive diversification as well as five critical phases to the business discovery process. Komninos et al. (2014) also put forward a model for the entrepreneurial discovery process based on their evaluation of the fields and areas of future productivity and boosting the aggregate value and correspondingly proposing productive diversification as a means of overcoming the crisis and recession.

The article "Facilitating an entrepreneurial discovery process for smart specialisation. The case of Poland" by Mieszkowski and Kardas (2015) approaches question around the extent to which initiatives such as prospective programmes, strategic research and development programmes and sector-based 


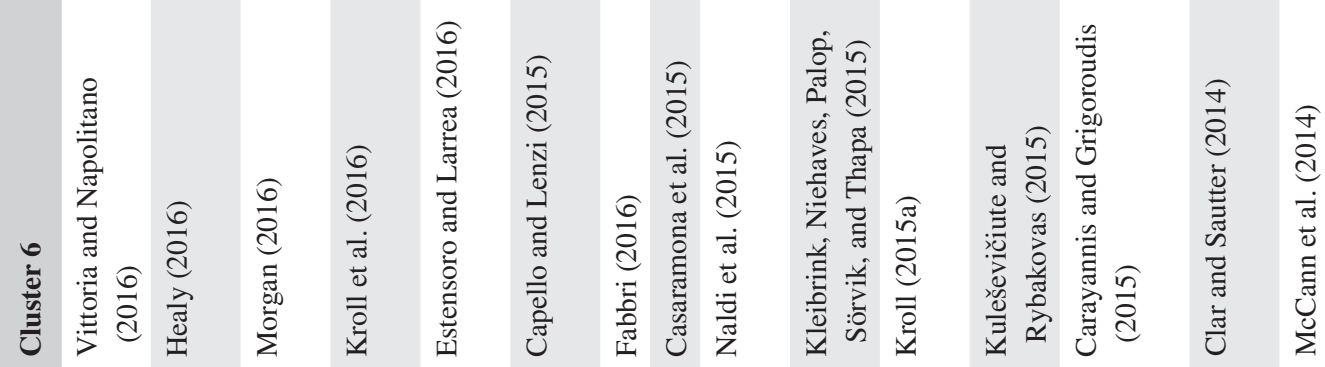

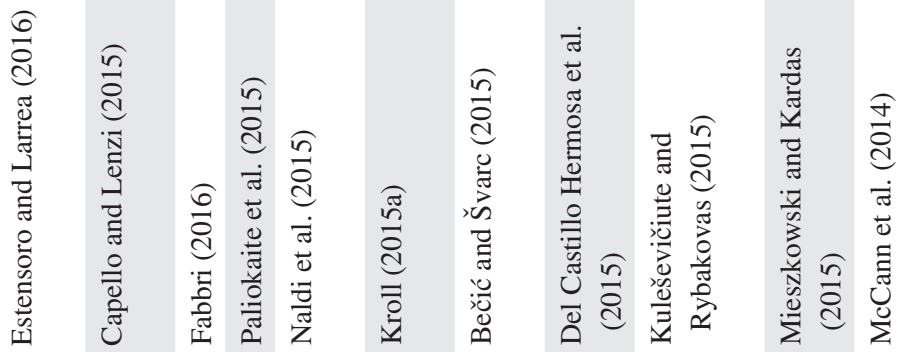

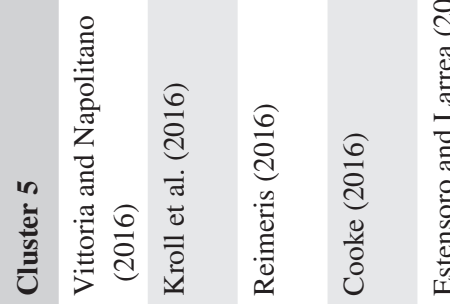

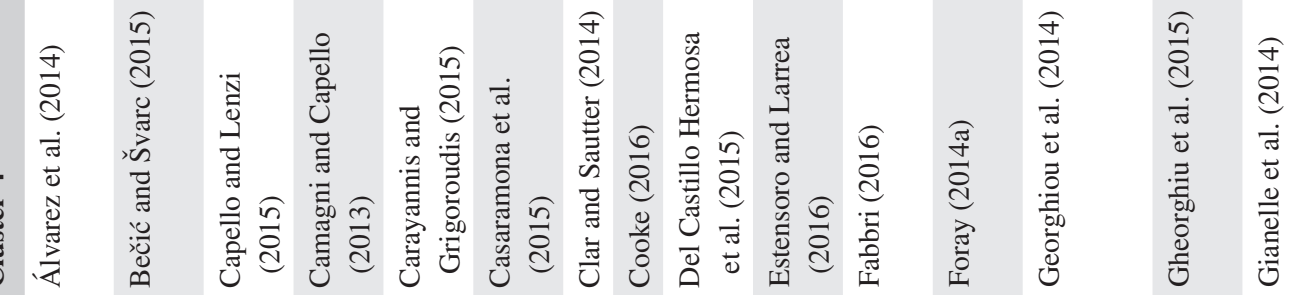

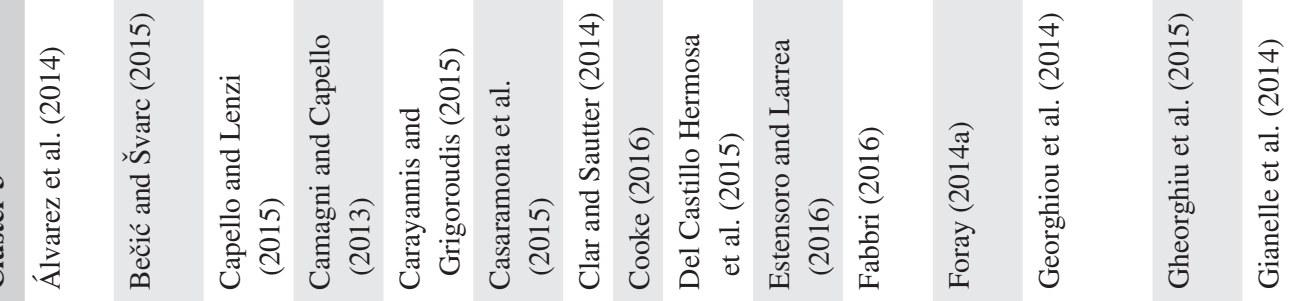

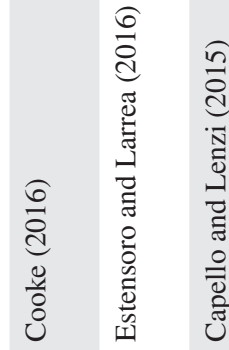




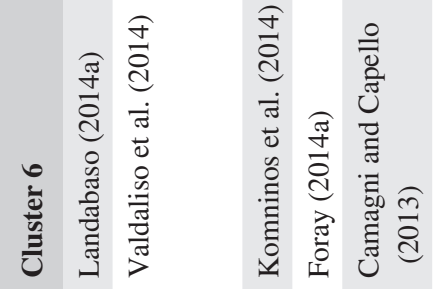

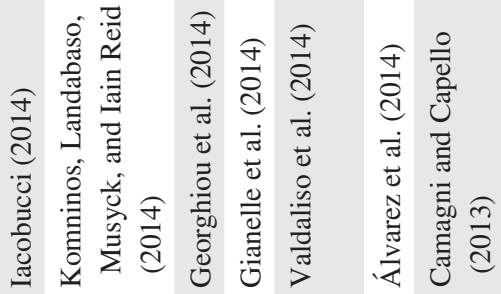

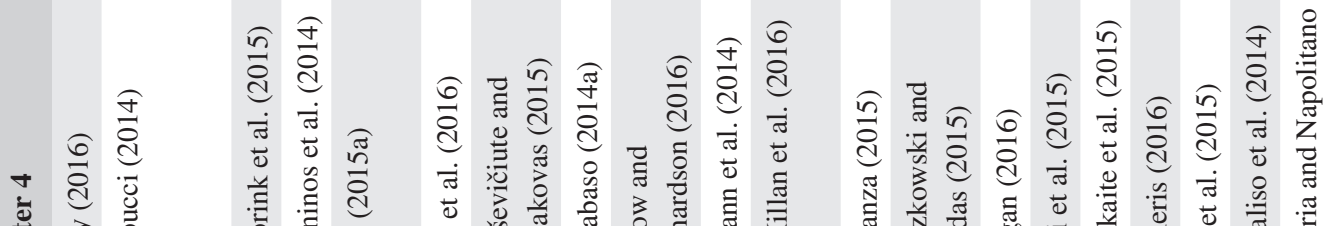

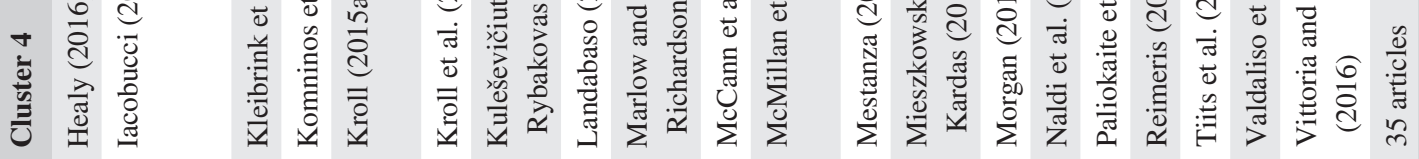

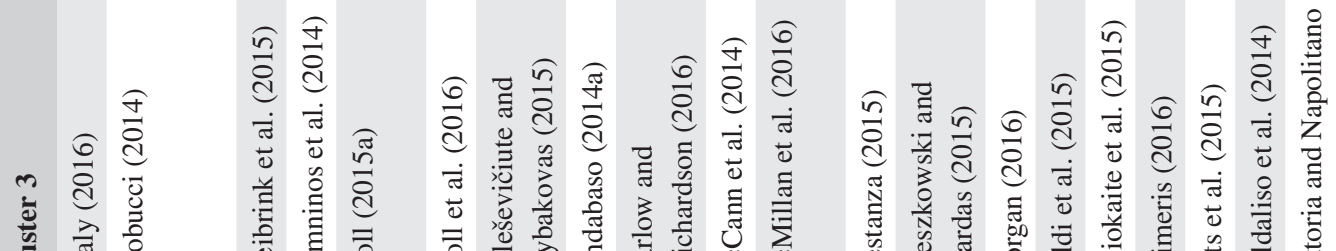

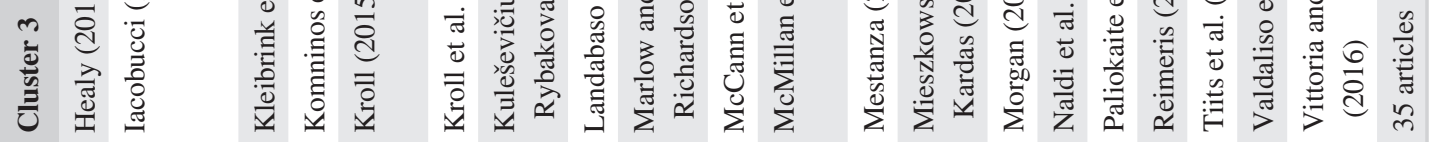

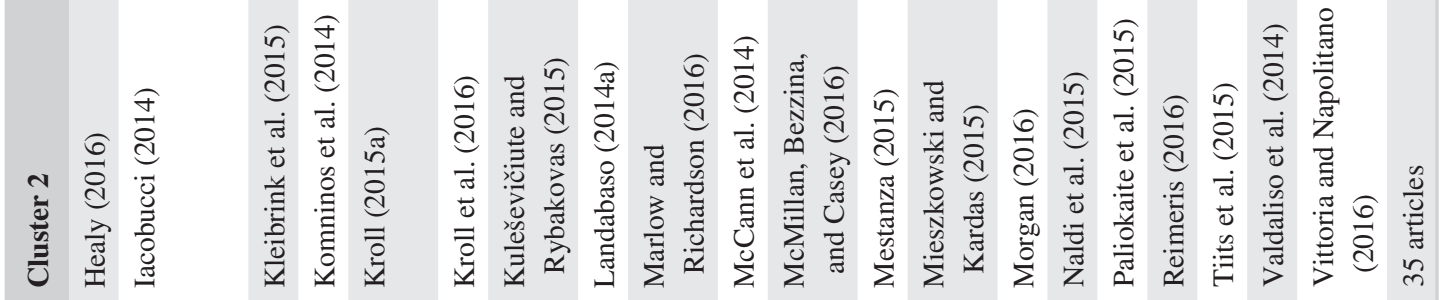

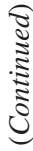

离

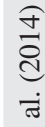

+- 苞

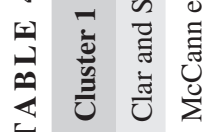


research development programmes simplify the process of entrepreneurial discovery for specialisation. By prospective, these authors mean the context of regional development, the study of the technical, scientific, economic and social causes that accelerate the development of the modern world as well as forecasting those situations that may derive from their combined influences. This study concludes that sectorial research programmes are more closely related with upwards approaches and structured towards demand in which the role of leadership is undertaken by entrepreneurs and business owners; thus, those most familiarised with the terms and conditions for entrepreneurial discovery processes (Mieszkowski \& Kardas, 2015).

The article "Smart specialization and entrepreneurial discovery: Theory and reality" by Del Castillo Hermosa et al. (2015) contributes towards clarifying the concept of entrepreneurial discovery both in theoretical and in practical terms. This study also contributes a set of recommendations about the role of entrepreneurial discoveries within a smart specialisation strategy, more specifically about the requirements for policies tailored to identifying and encouraging entrepreneurial discovery processes (Del Castillo Hermosa et al., 2015).

The article "A foresight toolkit for smart specialisation and entrepreneurial discovery" by Gheorghiu, Andreescu, and Curaj (2015) presents a set of prospective tools for smart specialisation and entrepreneurial discovery as well as setting out a detailed and complete plan.

We would reference how some articles, despite not directly approaching the other subthemes, do refer to them as important. For example, whenever some authors describe the smart specialisation process, they always mention entrepreneurial discovery (Komninos et al., 2014).

\subsection{2 | Smart specialisation, innovation and specialisation (clusters 2, 3 and 4)}

As regards the subthemes underpinning smart specialisation, innovation and specialisation (clusters 2, 3 and 4), as detailed above, these are present in all of the articles in the sample. The RIS3 concept thus proves implicit to the smart specialisation and innovation concepts and the reason explaining why these subthemes feature in all of the articles. Despite the word specialisation appearing as a subtheme, this emerges both in isolation and in conjunction with intelligent specialisation. Thus, we only consider smart specialisation in this analysis.

The article "Designing and implementing a smart specialisation strategy at the regional level: Some open questions" by Iacobucci (2014) discusses some of the theoretical justifications for and the problems to implementing RIS3. Furthermore, this also conveys suggestions about how to improve the design and implementation of RIS3.

Another article, with the title "Efforts to Implement Smart Specialization in Practice—Leading Unlike Horses to the Water" authored by Kroll (2015a) deals with implementing the RIS3 political agenda. This details how the main merit of RIS3 processes resides in their contribution to the change in governance practices and routines; however, these do not yet attain any measurable effects on policy (Kroll, 2015a).

The "Smart specialisation in European regions: Issues of strategy, institutions and implementation" article by McCann et al. (2014) seeks to demonstrate the various different approaches to smart specialisation under adoption by different EU regions/countries. McCann et al. (2014) furthermore refer to how susceptible these are to moulding by the respective institutional and governance contexts as well as by the specific regional economic characteristics prevailing. They arrive at the conclusion that smart specialisation is undergoing implementation in very different ways depending on the respective case across both the national and the regional levels. They also refer to how the different regional actions strongly depend on the governance relationships ongoing between the regional and local authorities (McCann et al., 2014). 
The article "Four minutes to four years: the advantage of recombinant over specialised innovation-RIS3 versus "smartspec"" by the author Cooke (2016) explores the political transition between the FEDER and RIS3 financing methodologies and identifying their various strengths and weaknesses. This also studies the ways in which RIS3 has been received, understood and implemented across three regions in Portugal (Cooke, 2016).

The article "Smart specialisation in Croatia: Between the cluster and technological specialisation" by Bečić and Švarc (2015) discusses the particularities to implementing the concept of smart specialisation in innovation follower countries and taking Croatia as the example. This study leads to the conclusion that the smart specialisation concept is a useful tool for replacing surplus policies (Bečić \& Švarc, 2015). Thus, there emerges a new set of policies based upon the concept of interconnecting specific areas subject to prior identification and structured by order of priority (Bečić \& Švarc, 2015).

Finally, the article "Collective entrepreneurship: the Basque model of innovation" by Morgan (2016) focuses upon the Basque Country. This region held a track record of success for regional transformation in the 1980s and 1990s. Morgan (2016) describes the objective of the article as explaining this experience and evaluating the implications for both within and beyond the Basque Country. The study examines how the Basque model of success is undergoing adaptation to the new smart specialisation strategy, thus, the most recent EU regional innovation programme for RIS3. Hence, the article sets out four key questions that need consideration within the scope of regional innovation policies: (a) a balance between continuity and novelty; (b) the problem of policy complexity; (c) the interactions between intra-regional and extra-regional learning processes; and (d) centred versus oriented strategies for approaching innovation through locally based networks.

\subsection{3 | Regional policies (cluster 5)}

The article "Regional innovation patterns and the EU regional policy reform: Toward smart innovation policies" by Camagni and Capello (2013) triggered the interest of the research community in this theme. According to Camagni and Capello (2013), the article fits within the debate on smart specialisation strategies and highlights the need to overcome the simplistic dichotomy between core and periphery in the EU and between an advanced "research field" (the core) and an "area of co-application." The article sets out a critique of the smart specialisation debate before suggesting a new taxonomy for innovative regions in the EU based upon their patterns of innovation (Camagni \& Capello, 2013). This further proposes innovation policies for each regional mode of innovation (Camagni \& Capello, 2013).

The article "Path dependence in policies supporting smart specialisation strategies: Insights from the Basque case" by Valdaliso et al. (2014) focuses upon the Basque Country. According to Valdaliso et al. (2014), the article's objective involves applying the theoretical structure of trajectory dependence to the policies enacted in support of research and innovation strategies for smart specialisation. This article aims to contribute towards the operationalisation of analysis focusing on the continuity of changes in innovation-based technological policies in support of RIS3 policies (Valdaliso et al., 2014). Valdaliso et al. (2014) state that other regions/countries learn about the challenges that European regions face from the analysis of the Basque case to the extent that they advance with the implementation of RIS3. This implementation should take place in accordance with the degree of maturity of the technological and innovation policies in effect in the region.

Finally, the article "Relevance and utility of European Union research, technological development and innovation policies for a smart growth" by Capello and Lenzi (2015) sets out an evaluation of the relevance and utility of technological development and innovation to research (Capello \& Lenzi, 
2015). The results convey how research funding, technological development and innovation generally hold relevance to boosting innovation (Capello \& Lenzi, 2015).

\subsection{4 $\quad$ Regional development (cluster 6)}

The article entitled "Smart specialization in a centralized state: strengthening the regional contribution in North East Romania" by Healy (2016) analyses the introduction of the RIS3 approach to Northeast Rumania. Healy (2016) states that "while the experience of developing a regional RIS3 provides strong benefits to learning, its effectiveness depends on support from institutional structures."

In turn, the article "What is smart rural development?" by Naldi et al. (2015) conceptually approaches and gathers together the ideas underpinning intelligent growth policies. This centres on intelligent growth from the perspective of rural regions (Naldi et al., 2015). The article also sets out a series of indicators deemed appropriate to intelligent rural development (Naldi et al., 2015).

\section{5 | CONCLUSIONS, STUDY LIMITATIONS AND FUTURE LINES OF RESEARCH}

As noted throughout this study, the theme under analysis remains fairly recent and more research is necessary. RIS3 is of extreme importance to the EU and constitutes the foundations for the strategy defined and under implementation through to 2020.

The literature review clearly demonstrates how RIS3 is an agenda for economic development adapted to the level of regions/countries. This strategy rests upon the concept of smart specialisation, innovation and sustainable development. The departure for RIS3 comes with the identification of the characteristics and specific assets of each region or country, a process in which all stakeholders should participate within the objective of establishing a vision of a sustainable future for the territory.

We verified through the literature that this theme is not consensual among all the opinions and decisions of the authors. Some opinions propose that imitative innovation represents the most appropriate path for the EU (Capello \& Lenzi, 2013), hence, benchmarking within the framework of implementing in regions those projects that have had or are having success in other regions (good copying). Other authors indicate how regions should specialise in the already established industries, thus they should not specialise in areas in which they do not already hold knowledge (Foray et al., 2009; Foray et al., 2012). Another opinion more diverging from that above maintains that regions should specialise and innovate in previously identified fields (Iacobucci, 2014; McCann \& Ortega-Argilés, 2014b).

Four key issues have been identified that need to be considered in the context of regional innovation policies: (a) a balance between continuity and novelty; (b) the problem of policy complexity; (c) the interactions between intra-regional and extra-regional learning processes; and (d) centred versus oriented strategies for approaching innovation through locally based networks (Morgan, 2016). The smart specialisation policies in regions or countries with small economies must create a strong synergy that includes innovation, knowledge and technology. Thus, they will create a strong and sustained growth strategy (Naldi et al., 2015). As a priority, policy makers and regional stakeholders should carefully define which sectors should specialise and which should be supported. Then, for a continuous implementation of an intelligent specialisation strategy, economic policies and regional structures need to be adapted to the new policies (Foray \& Goenaga, 2013). It is necessary to transform R\&D into the creation of new policies, so the concept will focus essentially on economic returns generated by R\&D (Tiits et al., 2015). Increasingly, R\&D investment is important for innovation to emerge more naturally and more frequently. Finally, it is necessary to measure the performance of the impact of the 
implemented measures, to add corrective measures in the case of necessity, as well as to implement new measures, so that the R\&D findings can generate a greater competitiveness and a greater economic performance.

The VosViewer results identified six subthemes/clusters. These subthemes also incorporate the results returned for the 50 most repeated words. We would note that a significant majority of these 35 articles fall within the framework of any of the 6 subthemes. Furthermore, we found that the subthemes made up of smart specialisation and innovation (clusters 2 and 3) were the widest reaching and most important for the study of RIS3. All of the articles approach these subthemes to a greater or lesser extent, which also reflects in the high density that they attain in Figure 4 (the red). The subtheme specialisation (cluster 4) gets classified under cluster 3 (smart specialisation). The subtheme business discovery (cluster 1) contains a total of 14 articles and hence attaining an average density level (yellow). Despite not reaching the same level of relevance as the first three subthemes, the latter always requires taking into consideration. In the regional policies (cluster 5) and regional development (cluster 6) subthemes, there are 22 articles in the first and 20 in the second. They display only a weak density level (green) (Figure 4). Thus, these constitute subthemes approached in a large proportion of the articles even while the focus never proves especially deep. We may therefore also state that all of these six subthemes duly interrelate with RIS3.

It was also concluded that the clusters 1, 5 and 6 are less studied than the others, and is pertinent that future research be developed in these subthemes.

We would also point to how the majority of the 35 articles in this study sample closely interconnect with business discovery as regards smart specialisation and hence to the process of selecting the strategies to be followed in the regions within the framework of the EU policy of governance through specialising in RIS3. There have already been a series of studies in various countries/regions on the RIS3 theme (Lithuania, the Basque Country, Malta, Northeast Romania, Germany, the United Kingdom, Tuscany - a region in western Italy, Spain, Portugal, Poland, Croatia); however, many others still require study. We would correspondingly mention that Portugal has already been subject to study by Cooke (2016) as regards RIS3. This article explores the transition of the FEDER policies to RIS3 and the respective prevailing strengths and weaknesses. This also details the ways in which three regions of Portugal (the Algarve, Centro and Norte regions) received, understood and implemented RIS3.

Some articles also include potential future lines of research on RIS3, which we summarised below. Hence, some mention the importance of regions displaying identical characteristics mutually learning about the best and worst practices in terms of strategies and implementation processes (Kleibrink, Niehaves, Palop, Sörvik, \& Thapa, 2015). Others, in turn, point to specific policies as those for adoption at the region/country level (Casaramona, Sapia, \& Soraci, 2015). There are also recommendations as regards future research, advocating qualitative (and even inductive) study methodologies for the field of business spirit and confidence that shapes the entrepreneurial discovery process, which is itself increasingly interrelated with smart specialisation and RIS3 (Vittoria \& Napolitano, 2016). As regards R\&D, Reimeris (2016) poses a question for future research work: Can the changes currently observed in the Lithuanian R\&D system be replicated and generalised to other regions/countries? (Reimeris, 2016). Another suggestion stems from studying the emergence and development of innovative partnerships and ideas as the immediate results from these prospective processes (Paliokaite et al., 2015). Other suggestions for future studies target the policies proposed by the EU and testing their effectiveness, potential impact and capacity to stimulate efficient knowledge transfer processes in Mediterranean partner countries (Casaramona et al., 2015) and the drafting of studies comparing the performances of economies before and after the implementation of RIS3. The proposals also identified comparing the RIS3 directives by region and comparing the performances returned by regions with similar characteristics.

As specifically regards bibliometric studies, future analysis might for example approach the articles in accordance with their methodologies (conceptual, quantitative, qualitative and mixed) and 
thereby quantify them, for instance, to analyse the literature applying conceptual, and qualitative methods of analysis and to develop the tendencies of the literature based on these methodologies. It may also include other areas underlying the theme that were not included in this research. These quantifications might then be handled by SPSS in order to reach more conclusions, for example verifying publications and thematic sub-areas. As limitations to this study, we would draw attention to how the methodology excluded publications other than scientific articles and correspondingly running the risk of having overlooked some relevant themes not otherwise approached in the published research articles. Furthermore, other keywords interrelated with this field might have been applied, such as "smart specialisation" and "regional policies" as well as including the other areas underlying this theme.

\section{ORCID}

João Lopes (D) http://orcid.org/0000-0002-2968-4026

\section{REFERENCES}

Acs, Z. J., Anselin, L., \& Varga, A. (2002). Patents and innovation counts as measures of regional production of new knowledge. Research Policy, 31(7), 1069-1085. https://doi.org/10.1016/S0048-7333(01)00184-6

Ahlqvist, T., Valovirta, V., \& Loikkanen, T. (2012). Innovation policy roadmapping as a systemic instrument for forward-looking policy design. Science and Public Policy, 39(2), 178-190. https://doi.org/10.1093/scipol/scs016

Álvarez, M. J., Fernández, R. I., \& Romera, R. (2014). Is eco-innovation a smart specialization strategy for Andalusia? One approach from the multivariate analysis. Revista De Estudios Regionales, 100, 171-195.

Asheim, B. T., Boschma, R., \& Cooke, P. (2011). Constructing regional advantage: Platform policies based on related variety and differentiated knowledge bases. Regional Studies, 45(7), 893-904. https://doi.org/10.1080/00343404.2010.543126

Asheim, B. T., \& Gertler, M. S. (2005). The geography of innovation: Regional innovation systems. In J. Fagerberg, D. C. Mowery, \& R. R. Nelson (Eds.), The oxford handbook of innovation (pp. 291-317). Oxford: Oxford University Press.

Audretsch, D. B., \& Feldman, M. P. (1996). R\&D spillovers and the geography of innovation and production. The American Economic Review, 86(3), 630-640.

Barroeta, B., Gómez Prieto, J., Paton, J., Palazuelos Martinez, M., \& Cabrera Giraldez, M. (2017). Innovation and regional specialization in Latin America (No. JRC106043). Joint Research Centre (Seville site).

Bečić, E., \& Švarc, J. (2015). Smart specialization in Croatia: Between the cluster and technological specialization. Journal of the Knowledge Economy, 6(2), 270-295. https://doi.org/10.1007/s13132-015-0238-7

Boden, M., Marinelli, E., Haegman, K., \& DosSantos, P. (2015). Bridging thinkers and doers: First policy lessons from the entrepreneurial discovery process in Eastern Macedonia and Thrace. Seville: Institute for Prospective and Technological Studies, Joint Research Centre.

Camagni, R. (1998). Sustainable urban development: Definition and reasons for a research programme. International Journal of Environment and Pollution, 10(1), 6-26. https://doi.org/10.1504/IJEP.1998.002228

Camagni, R. (2002). On the concept of territorial competitiveness: Sound or misleading? Urban Studies, 39(13), 2395-2411.

Camagni, R. (2009). Territorial capital and regional development. In R. Capello \& P. Nijkamp (Eds.), Handbook of regional growth and development theories (pp. 118-132). Chelthan, UK: Edward Elgar Publishing Limited.

Camagni, R., \& Capello, R. (2013). Regional innovation patterns and the EU Regional policy reform: Toward smart innovation policies. Growth and Change, 44(2), 355-389. https://doi.org/10.1111/grow.12012

Camagni, R., Capello, R., \& Lenzi, C. (2014). A territorial taxonomy of innovative regions and the European regional policy reform: Smart innovation policies. Scienze Regionali, 69-105.

Camagni, R., Capello, R., \& Nijkamp, P. (1998). Towards sustainable city policy: An economy-environment technology nexus. Ecological Economics, 24(1), 103-118. https://doi.org/10.1016/S0921-8009(97)00032-3

Capello, R. (2007). A forecasting territorial model of regional growth: The MASST model. Annals of Regional Science, 41(4), 753-787. https://doi.org/10.1007/s00168-007-0146-2

Capello, R. (2009). Spatial spillovers and regional growth: A cognitive approach. European Planning Studies, 17(5), 639-658. https://doi.org/10.1080/09654310902778045 
Capello, R. (2014). Smart specialisation strategy and the new EU cohesion policy reform: Introductory remarks. Scienze Regionali, 13(1), 5-15.

Capello, R., \& Lenzi, C. (2013). Territorial patterns of innovation and economic growth in European regions. Growth and Change, 44(2), 195-227. https://doi.org/10.1111/grow.12009

Capello, R., \& Lenzi, C. (2015). Relevance and utility of European Union research, technological development and innovation policies for a smart growth. Environment and Planning C: Government and Policy, 34(1), 52-72. https:// doi.org/10.1177/0263774X15614655

Carayannis, E., \& Grigoroudis, E. (2015). Quadruple innovation helix and smart specialization: Knowledge production and national competitiveness. Foresight and STI Governance, 10(1), 31-42. https://doi. org/10.17323/1995-459x.2016.1.31.42

Casaramona, A., Sapia, A., \& Soraci, A. (2015). How TOI and the quadruple and quintuple helix innovation system can support the development of a new model of international cooperation. Journal of the Knowledge Economy, 6(3), 505-521. https://doi.org/10.1007/s13132-015-0253-8

Clar, G., \& Sautter, B. (2014). Research driven clusters at the heart of (trans-) regional learning and priority-setting processes: The case of a smart specialization strategy of a German 'Spitzen' cluster. Journal of the Knowledge Economy, 5(1), 156-180. https://doi.org/10.1007/s13132-014-0180-0

Coffano, M., \& Foray, D. (2014). The centrality of entrepreneurial discovery in building and implementing a smart specialization strategy. Scienze Regionali, 13(1), 33-50. https://doi.org/10.3280/SCRE2014-001003

Cooke, P. (2001). Regional innovation systems, clusters, and the knowledge economy. Industrial and Corporate Change, 10(4), 945-974. https://doi.org/10.1093/icc/10.4.945

Cooke, P. (2012). Complex adaptive innovation systems: Relatedness and transversality in the evolving region. Abingdon, UK: Routledge.

Cooke, P. (2016). Four minutes to four years: The advantage of recombinant over specialized innovation-RIS3 versus 'smartspec'. European Planning Studies, 24(8), 1494-1510. https://doi.org/10.1080/09654313.2016.1151482

Del Castillo Hermosa, J., Elorduy, J. P., \& Eguía, B. B. (2015). Smart specialization and entrepreneurial discovery: Theory and reality. Revista Portuguesa De Estudos Regionais, 39(1), 5-22.

EC. (2014). National/regional innovation strategies for smart specialisation (RIS3). Cohesion Policy 2014-2020 Factsheet. Brussels, Belgium: European Commission.

Estensoro, M., \& Larrea, M. (2016). Overcoming policy making problems in smart specialization strategies: Engaging subregional governments. European Planning Studies, 24(7), 1319-1335. https://doi.org/10.1080/09654313.2016.11 74670

Fabbri, E. (2016). Strategic planning and foresight: The case of smart specialization strategy in Tuscany. Foresight, 18(5), 491-508. https://doi.org/10.1108/FS-06-2015-0036

Fagerberg, J. (2005). The Oxford handbook of innovation. Oxford, UK: Oxford University Press.

Falcomatà, S. A., Nucera, T., \& Tripodi, L. (2014). Place-based approach: A US-EU comparison. Advanced Engineering Forum, 11, 35-40.

Ferreira, M. (2011). A bibliometric study on Ghoshal's managing across borders. Multinational Business Review, 19(4), $357-375$.

Foray, D. (2013). The economic fundamentals of smart specialisation. Ekonomiaz, 83(2), 83-102.

Foray, D. (2014a). From smart specialization to smart specialization policy. European Journal of Innovation Management, 17(4), 492-507.

Foray, D. (2014b). Smart specialisation: Opportunities and challenges for regional innovation policy. London: Routledge.

Foray, D., David, P. A., \& Hall, B. H. (2009). Smart specialisation - the concept, knowledge economist's policy brief. Brussels, Belgium: European Commission.

Foray, D., David, P. A., \& Hall, B. H. (2011). Smart specialisation from academic idea to political instrument, the surprising career of a concept and the difficulties involved in its implementation (METI Working Paper, 2011-001). EPFL.

Foray, D., Goddard, J., Beldarrain, X. G., Landabaso, M., McCann, P., Morgan, K., ... Ortega-Argilés, R. (2012). Guide to research and innovation strategies for smart specialization (RIS3). Luxembourg City, Luxembourg: Publications Office of the European Union.

Foray, D., \& Goenaga, X. (2013). The goals of smart specialization. S3 policy brief series, 1, 2013. European Comission. 
Freire, P., \& d. S., (2013). Aumente a Qualidade e Quantidade de Suas Publicações Científicas: Manual para elaboração de projetos e artigos científicos. Curitiba, Brazil: Crv.

Georghiou, L., Uyarra, E., Scerri, R. S., Castillo, N., \& Harper, J. C. (2014). Adapting smart specialization to a micro-economy - The case of Malta. European Journal of Innovation Management, 17(4), 428-447. https://doi. org/10.1108/EJIM-03-2014-0026

Gheorghiu, R., Andreescu, L., \& Curaj, A. (2015). A foresight toolkit for smart specialization and entrepreneurial discovery. Futures, 80, 33-44.

Gianelle, C., Goenaga, X., Vázquez, I. G., \& Thissen, M. (2014). Smart specialization in the tangled web of European inter-regional trade. European Journal of Innovation Management, 17(4), 472-491. https://doi.org/10.1108/ EJIM-10-2013-0113

Hausmann, R., \& Rodrik, D. (2003). Economic development as self-discovery. Journal of Development Economics, 72(2), 603-633. https://doi.org/10.1016/S0304-3878(03)00124-X

Healy, A. (2016). Smart specialization in a centralized state: Strengthening the regional contribution in North East Romania. European Planning Studies, 24(8), 1527-1543. https://doi.org/10.1080/09654313.2016.1184233

Iacobucci, D. (2014). Designing and implementing a smart specialization strategy at regional level: Some open questions. Scienze Regionali, 13(1), 107-126. https://doi.org/10.3280/SCRE2014-001006

Jaffe, A. B. (1989). Real effects of academic research. American Economic Review, 79(5), 957-970.

Kleibrink, A., Niehaves, B., Palop, P., Sörvik, J., \& Thapa, B. E. P. (2015). Regional ICT Innovation in the European Union: Prioritization and performance (2008-2012). Journal of the Knowledge Economy, 6(2), 320-333. https://doi. org/10.1007/s13132-015-0240-0

Komninos, N., Landabaso, M., Musyck, B., \& Iain Reid, A. (2014). Smart specialization strategies in south Europe during crisis. European Journal of Innovation Management, 17(4), 448-471. https://doi.org/10.1108/EJIM-11-2013-0118

Kroll, H. (2015a). Efforts to implement smart specialization in practice-leading unlike horses to the water. European Planning Studies, 23(10), 2079-2098.

Kroll, H. (2015b). Weaknesses and opportunities of RIS3-type policies: Seven theses. Kahlsruhe, Germany: Fraunhofer ISI.

Kroll, H., Böke, I., Schiller, D., \& Stahlecker, T. (2016). Bringing owls to Athens? The transformative potential of RIS3 for innovation policy in Germany's Federal States. European Planning Studies, 24(8), 1459-1477. https://doi.org/1 0.1080/09654313.2016.1159666

Kuleševičiute, A. O., \& Rybakovas, E. (2015). Industrial preconditions for smart specialization of Lithuania regions. Public Policy and Administration, 14(1), 129-144.

Lancaster, W. (1991). Indexing and abstracting in theory and practice. London, UK: Library Association.

Landabaso, M. (2014a). Guest editorial on research and innovation strategies for smart specialization in Europe: Theory and practice of new innovation policy approaches. European Journal of Innovation Management, 17(4), 378-389. https://doi.org/10.1108/EJIM-08-2014-0093

Landabaso, M. (2014b). Time for the real economy: The need for new forms of public entrepreneurship. Scienze Regionali, 13(1), 127-140.

Marlow, D., \& Richardson, K. (2016). How smart is England's approach to smart specialization? A policy paper. European Planning Studies, 24(8), 1478-1493. https://doi.org/10.1080/09654313.2016.1179267

Maziak, D. E., Meade, M. O., \& Todd, T. R. (1998). The timing of tracheotomy: a systematic review. Chest, 114(2), 605-609.

McCann, P., Landabaso, M., \& Ortega-Argilés, R. (2014). Smart specialization in European regions: Issues of strategy, institutions and implementation. European Journal of Innovation Management, 17(4), 409-427. https://doi. org/10.1108/EJIM-05-2014-0052

McCann, P., \& Ortega-Argilés, O. (2014a). The role of the smart specialization agenda in a reformed EU cohesion policy. Scienze Regionali, 13(1), 15-32.

McCann, P., \& Ortega-Argilés, R. (2014b). Smart specialization in European regions: Issues of strategy, institutions and implementation. European Journal of Innovation Management, 17(4), 409-427.

McCann, P., \& Ortega-Argilés, R. (2015). Smart specialization, regional growth and applications to European Union cohesion policy. Regional Studies, 49(8), 1291-1302. https://doi.org/10.1080/00343404.2013.799769

McMillan, G. S., Bezzina, F., \& Casey, D. L. (2016). Smart specialization in Malta: A bibliometric look at aquaculture. International Journal of Technology Intelligence and Planning, 11(1), 51-61. https://doi.org/10.1504/ IJTIP.2016.074239 
Mestanza, G. C. (2015). Promoting innovation in EU regional and cohesion policy 2014-2020: Implementation in Spain. Investigaciones Regionales, 2015(33), 161-186.

Mieszkowski, K., \& Kardas, M. (2015). Facilitating an entrepreneurial discovery process for smart specialization. The case of Poland. Journal of the Knowledge Economy, 6(2), 357-384. https://doi.org/10.1007/s13132-015-0242-y

Morgan, K. (2016). Collective entrepreneurship: The Basque model of innovation. European Planning Studies, 24(8), 1544-1560. https://doi.org/10.1080/09654313.2016.1151483

Naldi, L., Nilsson, P., Westlund, H., \& Wixe, S. (2015). What is smart rural development? Journal of Rural Studies, 40, 90-101.

Ortega-Argiles, R. (2012). The transatlantic productivity gap: A survey of the main causes. Journal of Economic Surveys, 26(3), 395-419. https://doi.org/10.1111/j.1467-6419.2012.00725.x

Paliokaite, A., Martinaitis, Z., \& Reimeris, R. (2015). Foresight methods for smart specialisation strategy development in Lithuania. Technological Forecasting and Social Change, 101, 185-199.

Pelletier, J. S., Gill, R. S., Shi, X., Birch, D. W., \& Karmali, S. (2013). Robotic-assisted hepatic resection: A systematic review. International Journal of Medical Robotics, 9(3), 262-267. https://doi.org/10.1002/rcs.1500

Rauch, J. E. (1993). Productivity gains from geographic concentration of human-capital: Evidence from the cities. Journal of Urban Economics, 34(3), 380-400. https://doi.org/10.1006/juec.1993.1042

Reimeris, R. (2016). New rules, same game: The case of Lithuanian smart specialization. European Planning Studies, 24(8), 1561-1583. https://doi.org/10.1080/09654313.2016.1179722

Santini, C., Marinelli, E., Boden, M., Cavicchi, A., \& Haegeman, K. (2016). Reducing the distance between thinkers and doers in the entrepreneurial discovery process: An exploratory study. Journal of Business Research, 69(5), 1840-1844. https://doi.org/10.1016/j.jbusres.2015.10.066

Schumpeter, J. A. (1950). Capitalism, socialism, and democracy (3rd ed.). New York, NY: Harper [1962].

Smith, A. (1991). The wealth of nations. New York, NY: Random House.

Souza, A. (1988). Arqueologia brasileira (1975-1985): análise bibliométrica da literatura. Rio de Janeiro, Brazil: Universidade Federal do Rio de Janeiro.

Storper, M., \& Scott, A. J. (2009). Rethinking human capital, creativity and urban growth. Journal of Economic Geography, 9(2), 147-167. https://doi.org/10.1093/jeg/lbn052

Tahai, A., \& Meyer, M. J. (1999). A revealed preference study of management journals' direct influences. Strategic Management Journal, 20(3), 279-296. https://doi.org/10.1002/(SICI)1097-0266(199903)20:3aabbb279:AID-SMJ33aaabb3.0.CO;2-2

Tiits, M., Kalvet, T., \& Mürk, I. (2015). Smart specialization in cohesion economies. Journal of the Knowledge Economy, 6(2), 296-319. https://doi.org/10.1007/s13132-015-0239-6

Tiits, M., Kattel, R., Kalvet, T., \& Tamm, D. (2008). Catching up, forging ahead or falling behind? Central and Eastern European development in 1990-2005. Innovation-the European Journal of Social Science Research, 21(1), 65-85. https://doi.org/10.1080/13511610802002254

Titze, M., Brachert, M., \& Kubis, A. (2014). Actors and interactions-identifying the role of industrial clusters for regional production and knowledge generation activities. Growth and Change, 45(2), 163-190. https://doi. org/10.1111/grow.12047

Torre, A., \& Wallet, F. (2013). Innovation and governance of rural territories. In E. Coudel, H. Devautour, C. T. Soulardm, G. Faure, \& H. B. (Eds.), Renewing innovation systems in agriculture and food (pp. 147-164). Wageningen: Wageningen Academic Publishers.

Valdaliso, J., Landabaso, M., Magro, E., Navarro, M., Jose Aranguren, M., \& Wilson, J. (2014). Path dependence in policies supporting smart specialization strategies. European Journal of Innovation Management, 17(4), 390-408. https://doi.org/10.1108/EJIM-12-2013-0136

Vittoria, M. P., \& Napolitano, P. (2016). Large cultural networks and smart specialization: What is new in regional policy diagnostic analytics? Social Network Analysis and Mining, 6(1), 46. https://doi.org/10.1007/s13278-016-0359-4

Walsh, V. (1988). Technology and the competitiveness of small countries: Review. In C. Freeman \& B. Lundvall (Eds.), Small countries facing the technological revolution (pp. 37-66). London: Pinter.

White, H. D., \& Griffith, B. C. (1981). Author cocitation: A literature measure of intellectual structure. Journal of the American Society for Information Science, 32(3), 163-171. https://doi.org/10.1002/asi.4630320302

White, H. D., \& McCain, K. W. (1998). Visualizing a discipline: An author co-citation analysis of information science, 1972-1995. Journal of the American Society for Information Science, 49(4), 327-355.

Yu, J. B., \& Jackson, R. (2011). Regional innovation clusters: A critical review. Growth and Change, 42(2), 111-124. https://doi.org/10.1111/j.1468-2257.2011.00546.x 
Zhi, W., Yuan, L., Ji, G. D., Liu, Y. S., Cai, Z., \& Chen, X. (2015). A bibliometric review on carbon cycling research during 1993-2013. Environmental Earth Sciences, 74(7), 6065-6075. https://doi.org/10.1007/s12665-015-4629-7

How to cite this article: Lopes J, Ferreira JJ, Farinha L. Innovation strategies for smart specialisation (RIS3): Past, present and future research. Growth and Change. 2019;50:38-68. https://doi.org/10.1111/ grow. 12268 


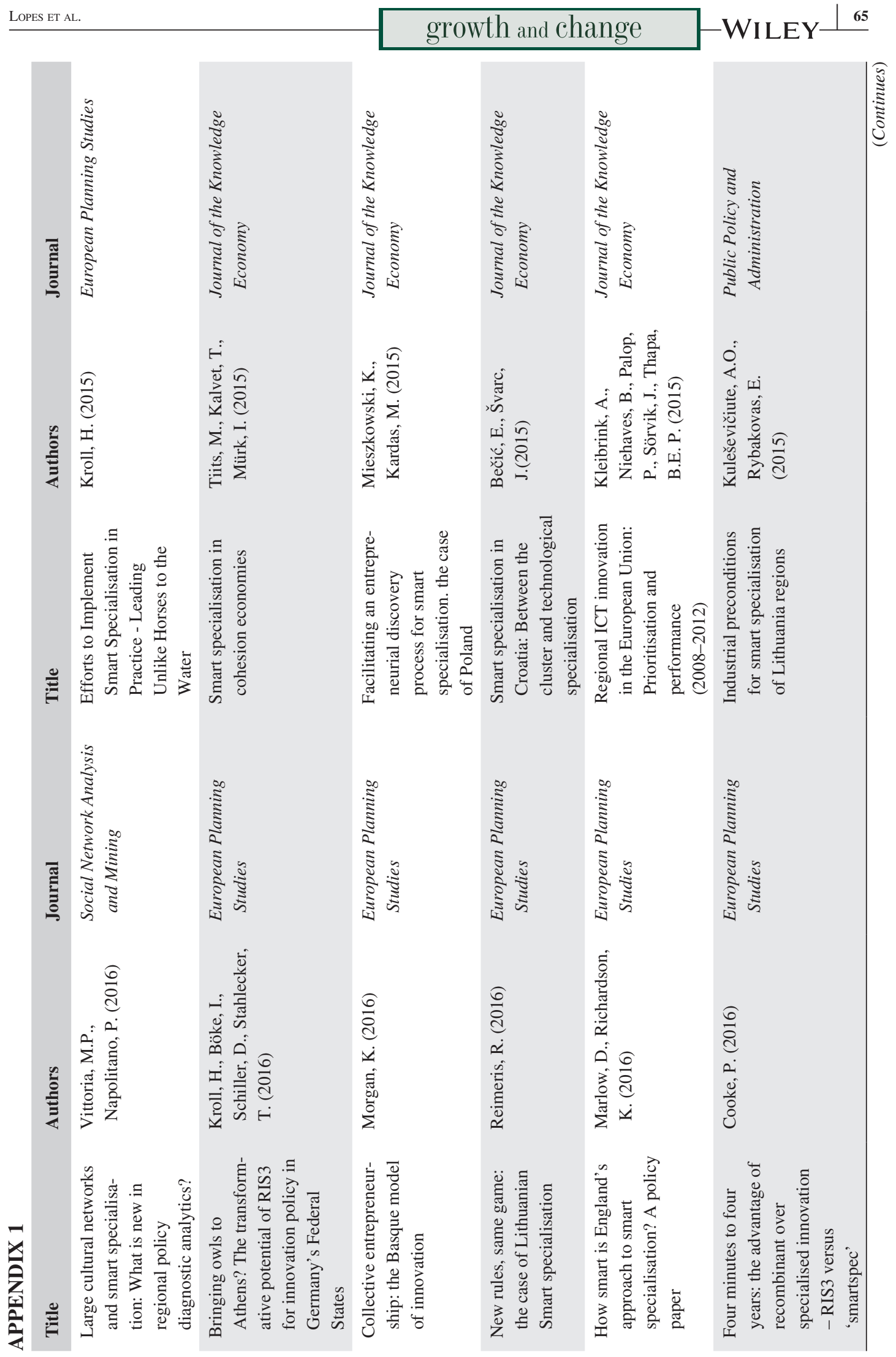



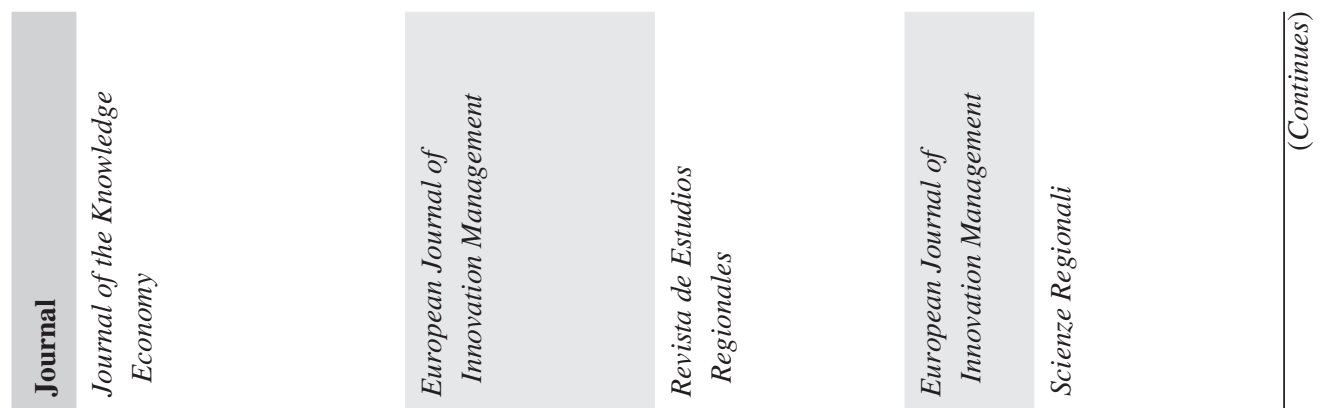

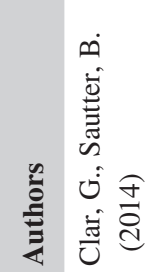
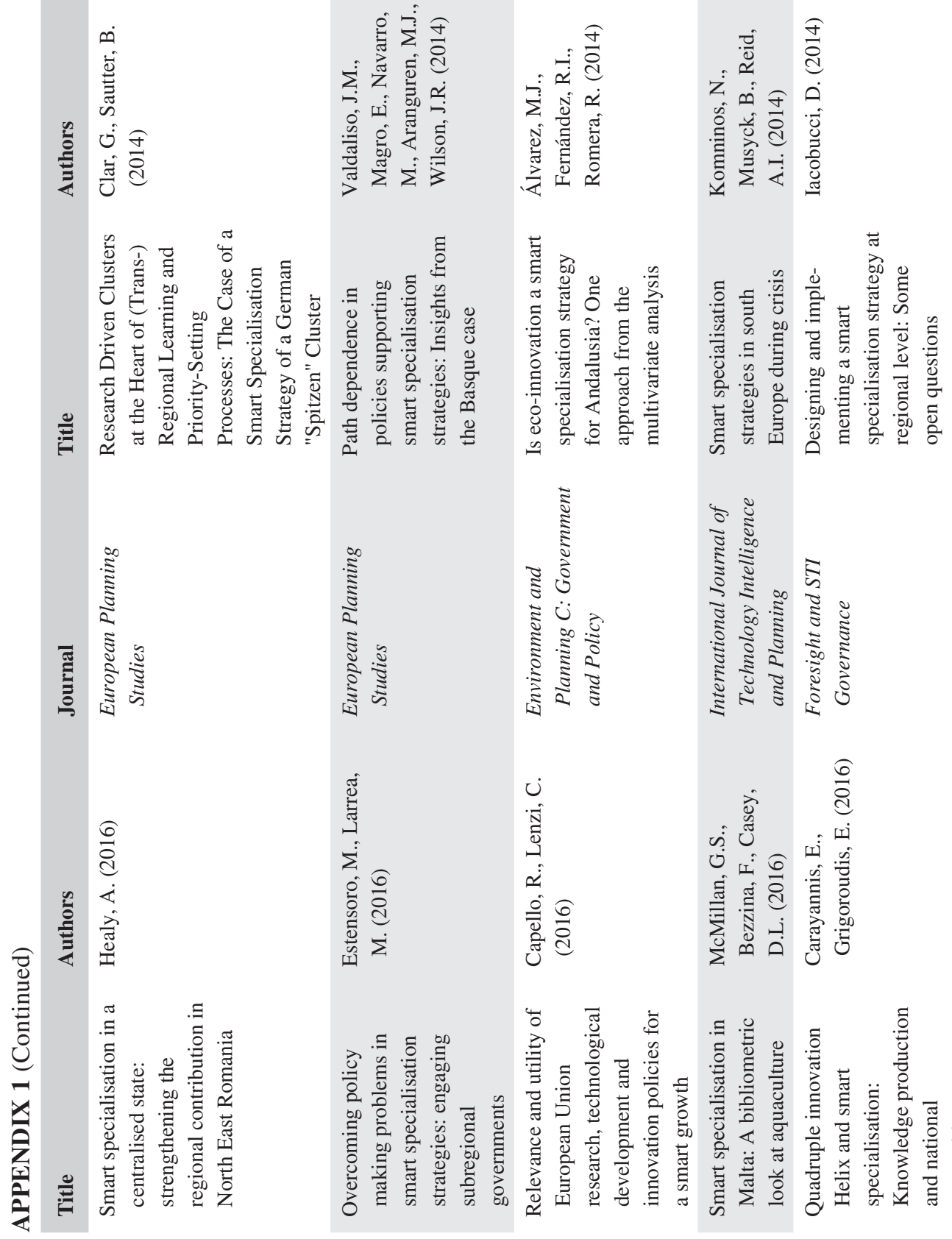

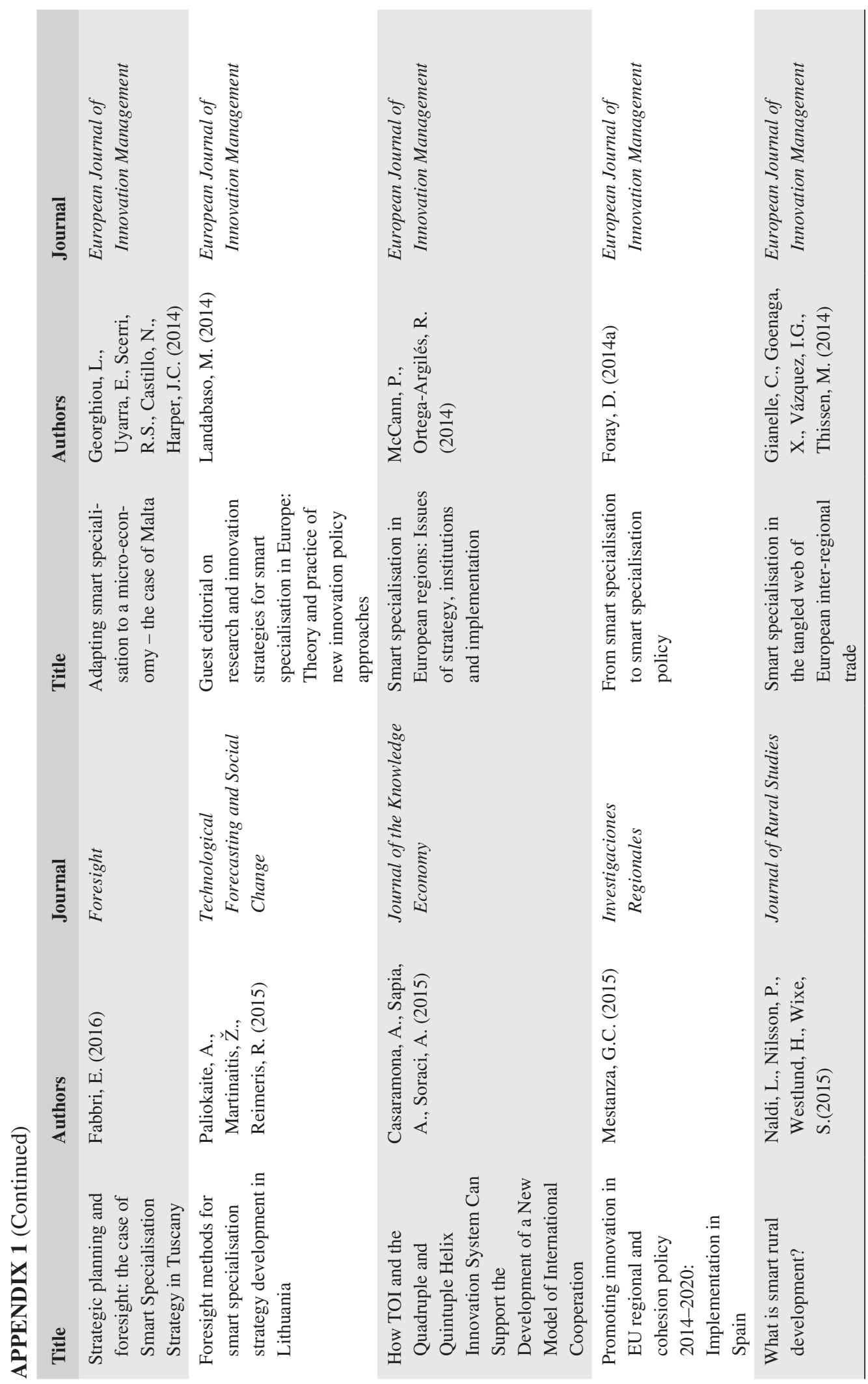

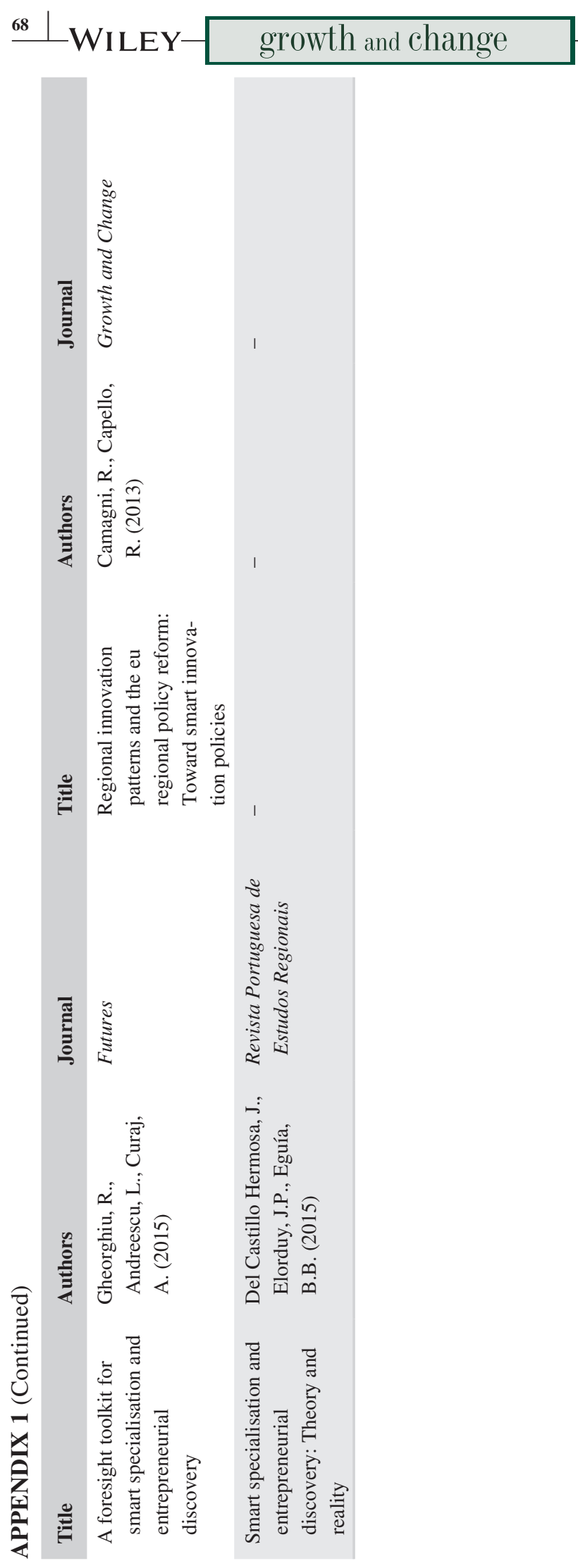